\title{
Changes in Dewatering Between the Thermophilic and Mesophilic Stages in TPAD Systems
}

\author{
Jason L. Bivins
}

Thesis submitted to the faculty of Virginia Polytechnic Institute and State University in partial fulfillment of the requirements for the degree of

\section{MASTER OF SCIENCE}

in

\section{ENVIRONMENTAL ENGINEERING}

\author{
John T. Novak, Chair \\ Nancy G. Love \\ Clifford W. Randall
}

September 2, 2000

Blacksburg, Virginia

Keywords: Thermophilic, mesophilic, anaerobic digestion, dewatering, conditioning, biopolymer 


\title{
Changes in Dewatering Between the Thermophilic and Mesophilic Stages in TPAD Systems
}

\author{
by \\ Jason L. Bivins \\ Committee Chairman: John T. Novak \\ Environmental Engineering
}

\begin{abstract}
Temperature-phased anaerobic digestion (TPAD) has become increasingly appealing in recent years due to the pathogen destruction capabilities of the system. However, there has also been concern about the dewatering properties of the sludges created by these systems. A laboratory study was conducted at Virginia Tech to determine the effect of thermophilic solids retention time (SRT) on sludge dewatering properties, to characterize system parameters associated with dewatering, and to understand the mechanisms causing changes in dewatering properties between the thermophilic and mesophilic phases. The study showed that while anaerobic digestion caused dewatering properties to deteriorate, sludges varied little with thermophilic SRT. Acidogenesis was essentially complete after 1.5 days. Subsequent mesophilic digestion resulted in little change to dewatering properties and modest reductions in conditioning doses, but substantial reductions in biopolymer (protein + polysaccharides) occurred. It appears that thermophilic anaerobic digestion creates or releases colloidal materials that cause dewatering to be poor and subsequent mesophilic digestion for 15 days does little to improve sludge properties of TPAD systems.
\end{abstract}




\section{ACKNOWLEDGMENTS}

I am extremely grateful for the opportunity to work under the direction of my major professor, Dr. John Novak. Words cannot express my appreciation for his support and guidance. I would also like to thank my committee members for their time and support. I never realized how respected each of the members of my committee were until after the completion of my research. As a process engineer, I see their marks on the field of environmental engineering on a daily basis.

I would also like to thank Dr. Sudhir Murthy for his invaluable guidance during the initial stages of my research. I appreciate the help provided by Chris Muller and Steve Cox in the lab. I would like to thank Dr. Matt Higgins for his guidance during the enzymatic activity tests. The technical assistance provided by Julie Petruska and Jody Smiley is also greatly appreciated. I thoroughly enjoyed sharing the lab with Scott Crosswell and Jeff Zoeckler.

I reserve the deepest appreciation for my parents, David and Bonnie Bivins. This degree and many other accomplishments in my life would not have been possible without their love and support. 


\section{TABLE OF CONTENTS}

\begin{tabular}{|c|}
\hline $\mathrm{CT}$ \\
\hline KNOWLEDG \\
\hline ABLE OF CONTENTS \\
\hline LIST OF FIGURES. \\
\hline 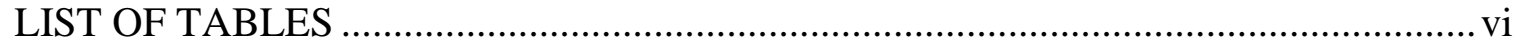 \\
\hline 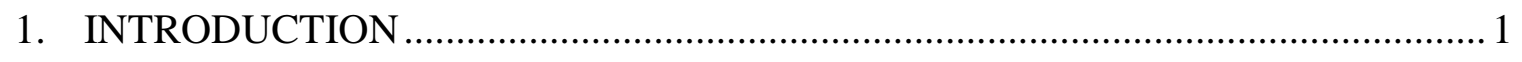 \\
\hline 2. $\quad$ LITERATURE REVIEW .................................................. \\
\hline 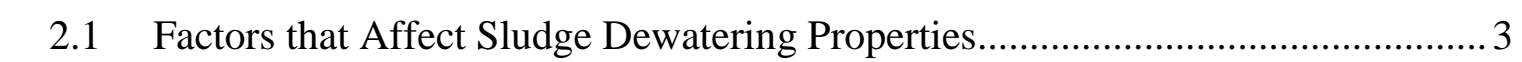 \\
\hline Biopolymer. \\
\hline 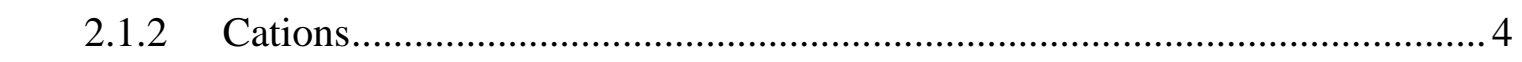 \\
\hline 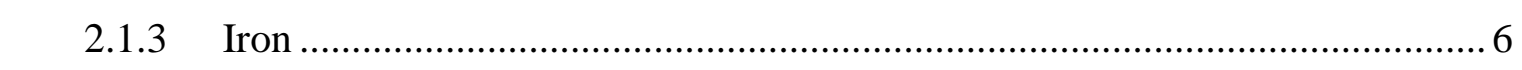 \\
\hline $2.1 .4 \quad$ Enzymatic Activity......................................................................................... \\
\hline 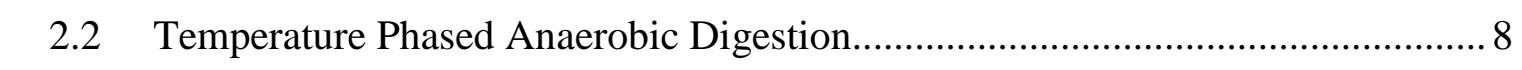 \\
\hline Process. \\
\hline 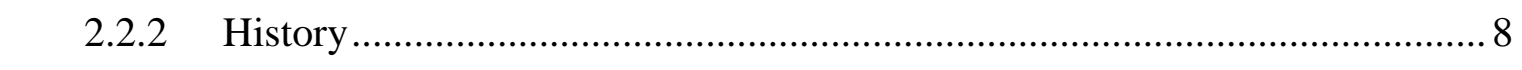 \\
\hline 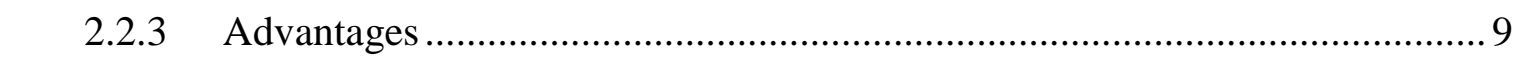 \\
\hline Disadvantages... \\
\hline 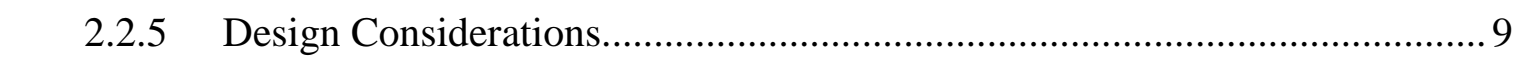 \\
\hline Research \\
\hline $2.2 .7 \quad$ Full-Scale Systems ................... \\
\hline 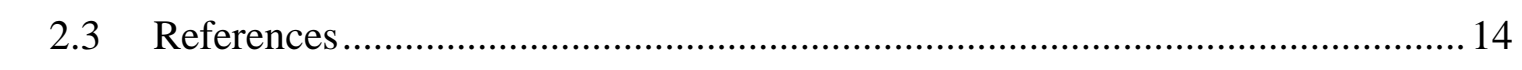 \\
\hline 3. MANUSCRIPT \\
\hline $4 . \quad$ SUMMARY OF EXPERIMENTAL SYSTEM DATA ........................................... 36 \\
\hline 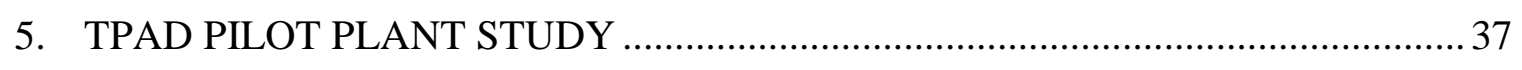 \\
\hline 6. $\quad$ ENGINEERING SIGNIFICANCE .................................................................40 \\
\hline \\
\hline
\end{tabular}




\section{LIST OF FIGURES}

FIGURE 1: EFFECT OF THERMOPHILIC (T) AND MesophiLIC (M) ANAEROBIC Digestion

ON THE DEWATERING RATE OF WASTE ACTIVATED SLUDGE ...................28

FIGURE 2: EFFECT OF THERMOPHILIC AND MESOPHILIC ANAEROBIC DIGESTION ON

POLYMER CONDITIONING CHEMICAL DOSE REQUIREMENTS .....................29

FIGURE 3: Size Distribution of Filterable Protein, Polysaccharides, and COD

ACROSS THE DIGESTERS....................................................................... 30

FIGURE 4: COLLOIDAL COD CONCENTRATION BEFORE CONDITIONING VERSUS OPTIMUM

POLYMER DOSE REQUIREMENT..................................................... 31

FIGURE 5: LEUCINE-AMINOPEPTIDASE ACTIVITY IN THE DIGESTERS............................ 32

FIGURE 6: VOLATILE FATTY ACID CONCENTRATION ACROSS THE DIGESTERS................33

FIGURE 7: FILTERABle AMMONIUM ION $\left(\mathrm{NH}_{4}-\mathrm{N}\right)$ CONCENTRATION ACROSS THE

DIGESTER ....................................................................................... 34

FIGURE 8: Filterable MAGnesium AND Phosphate $\left(\mathrm{PO}_{4}-\mathrm{P}\right)$ CONCENTRATION ACROSS

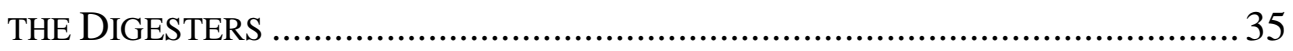




\section{LIST OF TABLES}

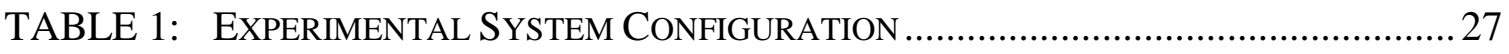

TABLE 2: SUMMARY OF EXPERIMENTAL SYSTEM DATA (AVERAGE VALUES)...............36

TABLE 3: $\quad$ PILOT Plant SLUDGE CHARACTERIZATION STUDY ................................. 39

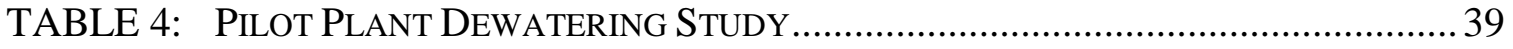




\section{INTRODUCTION}

Prior to 1992, technology and process based standards governed the land application of sewage sludges. New regulations pertaining to land application mandate higher pathogen destruction requirements than are typically feasible with conventional anaerobic digesters operated at mesophilic temperatures (typically $35^{\circ} \mathrm{C}$ ). These higher standards, often referred to as Class A biosolids, are defined within U.S. EPA 40 CFR Part 503 Standards for the Use and Disposal of Sewage Sludge. Many wastewater treatment facilities do not have access to the site restricted land application areas required for Class B sludges. Approximately 40 percent of all municipal sewage sludges are currently land applied or marketed to proprietary organizations (Stukenberg et al. 1992). Therefore, the impact of these regulations has been and will continue to be substantial. The capacity to produce Class A biosolids maximizes the ultimate disposal options of biosolids by wastewater treatment facilities.

For decades, conventional anaerobic digestion (single-stage/mesophilic) has been the standard for sludge stabilization in large-scale municipal wastewater treatment plants. The rate limiting steps associated with anaerobic digestion are hydrolysis and methanogenesis. The goal of the two-phase system, introduced in the 1970's, was to optimize the environments for specific biological reactions by confining hydrolysis and acidogenesis to a single bioreactor, while allowing acetogenesis and methanogenesis to occur in a second reactor in series (Ghosh 1987). Advantages of the two-phase system include increased sludge stabilization and gasification as well as improved process stability. However, some studies have suggested that the increase in efficiency does not necessarily justify the increased operational cost of the two-phase anaerobic digestion system (Bhattacharya et al 1996). Thermophilic (typically $55^{\circ} \mathrm{C}$ ) digesters were studied in single-phase (Garber 1977) and two-phase configurations (Lee et al. 1989). Higher pathogen destruction at shorter solids retention times was observed in both systems than typically occur in conventional mesophilic digestion systems. However, high volatile fatty acid concentrations, leading to lower process stability and odor problems, made this system less appealing.

Several configurations have been proposed that combine both thermophilic and mesophilic digestion. The DuPage 2-phase digestion system consists of a mesophilic 
phase (1.5 days) followed by a thermophilic phase (10 days) in series (Wilson 1998). The thermophilic phase achieves pathogen destruction to enable Class A sludge classification. Aeration may be required after thermophilic digestion for sludge polishing and deodorization (Forbes and Wooley 1998).

The Anaerobic Stabilization Thermophilic/Mesophilic (ASTM) system was developed in Germany and has been implemented at both small and large scale plants in Europe. This system consists of a thermophilic phase (2-5 day SRT) followed by a mesophilic phase (10-15 day SRT) (Oles et at. 1997). The U.S version of this system, Temperature Phased Anaerobic Digestion (TPAD), was developed (early 1990's) and patented (June 1996) by Richard Dague and coworkers at Iowa State University (Han and Dague 1998). The ASTM and TPAD systems are very similar and will be discussed as equivalents. The system described in this study will be referred to as a TPAD system for convenience. Many of the problems associated with single and two-phase, mesophilic or thermophilic digestion systems are overcome by the TPAD configuration. High concentrations of VFA's are created during thermophilic digestion; however, VFA's are greatly reduced during mesophilic digestion, enabling greater process stability. Due to high VFA concentrations, the thermophilic phase of this system is still odorous; however, fixed covers on the thermophilic digesters can alleviate this problem (Wilson and Dichtl 1998). Most importantly, Class A biosolids can be achieved by this system at reasonable SRT's due to the high pathogen destruction in the thermophilic phase (Streeter et al. 1997).

One concern about the TPAD system and other thermophilic anaerobic processes is that the dewatering properties of the digested biosolids may be difficult and expensive to dewater. Rust (1998) found that increased temperatures resulted in higher capillary suction times (CST), increases in polymer conditioning requirements, and higher biopolymer concentrations in solution. The increase in polymer conditioning requirements was attributed to the release of biopolymer (protein and polysaccharides) into solution and the biopolymer concentration increased with both temperature and digestion time. 


\section{LITERATURE REVIEW}

Most research efforts pertaining to temperature phased anaerobic digestion (TPAD) have focussed on the pathogen and volatile solids destruction capabilities of the system. The dewatering properties of TPAD sludges have not been addressed in the literature. However, as with any stabilization process, the dewatering properties of the finished product can have a major impact on the overall economic performance of the process. A summary of the literature pertaining to TPAD systems and the factors that affect sludge dewatering properties follows.

\subsection{Factors that Affect Sludge Dewatering Properties}

\subsubsection{Biopolymer}

The presence of biopolymer in sludges originates from formation during microbial metabolism, release during cell lysis, or the wastewater itself (Grady et al. 1998). Biopolymers, specifically proteins and polysaccharides, have a major impact on sludge dewaterting properties. Novak et al. (1977) concluded that soluble biopolymer has a greater impact on sludge dewatering properties than floc-bound biopolymer. The soluble biopolymer fraction can be reduced via bioflocculation or microbial decay (Novak et al. 1977). Biopolymer and cell surfaces are negatively charged. Therefore, for bioflocculation to occur, a bridge must be formed between the two surfaces. Higgins and Novak (1997c) proposed a bioflocculation model where proteins with lectin-like properties bind polysaccharides to adjacent proteins via divalent cations.

Particle size distribution can have a major impact on sludge dewaterability. An increase in the smaller colloidal fraction typically has an adverse effect on sludge dewatering properties. Floc deterioration can lead to the release of biopolymer into solution, which can increase the smaller size fraction. Novak et al. (1988) suggested that smaller particles ( $<40$ microns) in a broad particle size distribution tend to blind (migration of sludge particles into cake pores) sludge during filtration, especially in anaerobically digested sludge.

Rust (1998) analyzed the effect of biopolymer on dewatering properties during aerobic and anaerobic digestion. The author concluded that an increase in the total soluble biopolymer concentration was detrimental to dewatering properties during both 
aerobic and anaerobic digestion. During anaerobic digestion, protein was the dominant fraction of soluble biopolymer. However, during aerobic digestion, polysaccharides accounted for the majority of the soluble biopolymer. This finding is consistent with Morgan et al. (1990) who also reported that the ratio of proteins to carbohydrates is approximately 3:1 for anaerobically digested sludges. Reports of protein to carbohydrate ratios from aerobically digested sludges have been inconsistent in literature (Morgan et al. 1990). Rust also concluded that the soluble protein fraction accounted for a significantly higher portion of the polymer demand than the soluble polysaccharide fraction.

During digestion, biopolymer can accumulate in solution when unfavorable environmental conditions exist for bacterial metabolism. The mechanisms that control bacterial selectivity for biopolymer degradation are not fully understood. Breure et al. (1986) concluded protein degradation is inhibited when high concentrations of carbohydrates are present, leading to protein accumulation. Cofner and Logan (1997a) speculate that the degradation of proteins (1997a) and polysaccharides (1997b) occur via cell-bound hydrolysis. The degradation of protein can lead to extremely foul odors when proteins are present in high concentrations (Metcalf and Eddy 1991).

Poxon and Darby (1997) concluded that a relationship between dewatering properties and the total polysaccharide concentration was dependent upon digester feed composition, suggesting that qualitative (biochemical) parameters pertaining to polysaccharides are more significant than quantitative parameters. Horran and Eccles (1986) proposed that changes in floc properties were the result of changes in the structure of polysaccharides. The authors suggested that the key to solid-liquid separation is to control the type and amount of biopolymer produced. However, as Horran and Eccles acknowledged, this would require a much greater understanding of the microorganisms responsible for biopolymer production and the factors that affect biopolymer production.

\subsubsection{Cations}

Research conducted at Virginia Tech in recent years has yielded a greater understanding of floc structure. The ratio and concentration of cations can have a major impact on the settling and dewatering properties of activated sludge (Higgins and Novak 
1997a). Higgins and Novak suggested that cations become incorporated within the microbe-biopolymer network, creating a dense floc that is more resistant to shear. A laboratory analysis indicated that a cation imbalance (monovalent to divalent ratio in excess of two) could result in increased conditioning requirements. During field verification of the laboratory analysis, it was concluded that by adjusting the cation content, the settling and dewatering properties of activated sludges can be improved, leading to a reduction in conditioning requirements (Higgins and Novak 1997b).

A laboratory analysis of an activated sludge from an industrial wastewater treatment plant (WWTP) suggested that as the monovalent to divalent cation ratio was increased via the addition of $\mathrm{NaCl}$ to the feed, the biopolymer concentration increased, indicating a release of this material from the floc surface (Novak et al. 1998). It was also concluded from this study that the addition of magnesium reduced effluent suspended solids and increased floc strength.

Another laboratory analysis of activated sludge from an industrial WWTP suggested that the addition of divalent cations (calcium and magnesium) could have a major impact on settling and dewatering properties (Murthy et al. 1998). During field trials, the addition of magnesium sulfate to the feed sludge increased floc strength, leading to an improvement in dewatering properties. Results from the field studies also led Murthy et al. to propose that excessive concentrations of ammonium ions might have an adverse effect on sludge dewatering properties in a manner similar to the monovalent cation sodium (1998).

Murthy and Novak (1998) also conducted research on the effect of potassium on sludge settling and dewatering properties. It was concluded that the optimal potassium concentration for dewatering was found to be in the range of $0.25-0.50 \mathrm{meq} / \mathrm{L}$. The authors speculated that the potassium deficiency was related to cell nutrient requirements as opposed to physical/chemical factors. However, similar to previous studies involving the monovalent cation sodium, the authors concluded that excessive potassium concentrations $(>0.50 \mathrm{meq} / \mathrm{L})$ can be detrimental to activated sludge dewatering properties from a physical/chemical standpoint (Murthy and Novak 1998)

Murthy and Novak (1999) conducted a laboratory-scale analysis to determine the effect of cation content on the dewatering properties of aerobically digested sludge. 
Similar to activated sludge, it was concluded during this study that by achieving a proper balance between monovalent and divalent cations, dewatering properties are improved, leading to a reduction in conditioning requirements (Murthy and Novak 1999)

Rust (1998) analyzed the effect of cations on dewatering properties during aerobic and anaerobic digestion. The author concluded that calcium and magnesium promote bioflocculation during digestion by binding biopolymer. Rust also proposed that calcium is more effective than magnesium in binding to polysaccharides during digestion.

\subsubsection{Iron}

Jackson-Moss and Duncan (1990) demonstrated that although iron is a nutrient that is required by methanogens for biological growth, at concentrations in excess of $1,750 \mathrm{mg} / \mathrm{L}$, iron can inhibit anaerobic digestion. However, the presence of iron in moderate concentrations is generally beneficial to bioflocculation. Rust (1998) proposed that both ferrous iron and iron hydroxide promotes bioflocculation by serving as a bridge between proteins and the floc.

Rasmussen and Nielsen (1996) found that up to $10 \%$ of the total organic matter (bacteria, organic colloids, and extracellular polymeric substances) was released from activated sludge flocs when $\mathrm{Fe}(\mathrm{III})$ was reduced via introduction of sulfide into the system. Rasmussen and Nielsen concluded that the presence of sulfide appears to have a detrimental affect on sludge dewatering properties by reducing $\mathrm{Fe}$ (III) to $\mathrm{Fe}$ (II) as $\mathrm{FeS}$ (1996).

Warren and Ferris (1998) demonstrated that under anaerobic conditions (activated sludge storage), $\mathrm{Fe}(\mathrm{III})$ serves as an electron acceptor and almost all of the $\mathrm{Fe}$ (II) produced remained associated with the floc matrix. During anaerobic digestion, $\mathrm{Fe}(\mathrm{III})$ is reduced to $\mathrm{Fe}$ (II) either chemically or biologically, commonly resulting in hydroxide, carbonate, and sulfide precipitates. Warren and Ferris speculate that the reduction of $\mathrm{Fe}$ (III) may also cause a release of chemically bound phosphate to solution during anaerobic conditions (1998). 


\subsubsection{Enzymatic Activity}

Recently, several research efforts have attempted to correlate wastewater composition and/or microbial selectivity for specific substrates to enzymatic activity. Enzymes are proteins with the ability to increase the rate of chemical reactions by reducing the activation energy required to make a reaction proceed with the conversion of substrates to products (Madigan et al. 1997). During the hydrolysis phase of anaerobic digestion, microoganisms convert high molecular weight compounds (lipids, polysaccharides, proteins, and nucleic acids) into low-molecular weight compounds (carbon sources and electron donors) via extracellular enzymes (Metcalf and Eddy 1991). By establishing a correlation between enzymatic activity and substrate degradation, sludge environments can be manipulated to optimize process efficiency.

Frolund et al. (1995) monitored the enzymatic activity of activated sludge over a 3-month period and observed large accumulations of enzymes in the floc matrix. The enzymes were not only connected to bacteria, but also to biopolymer. Prior to biopolymer release, significant fractions of enzymes were released. However, no known connection was made between wastewater chemical composition and enzymatic activity. Also of significance, leucine aminopeptidase activity was large compared to other specific enzymes tested (Frolund et al. 1995). Aminopeptidases free amino acids from peptides resulting from the catabolism of proteins by proteases (Gonzales and RobertBaudony 1996).

Nybroe et al. (1992) examined whether changes in treatment plant operations was reflected in the activity of enzymes. However, similar to Frolund et al. (1995), no correlation could be made between enzymatic activity and the process parameters monitored. However, the authors observed significantly higher alanine-peptidase activities in anaerobically digested sludge compared to activated sludge. Nybroe et al. (1992) suggested that the variation in peptidase activity could be attributed to solubilization of nitrogenous material during the hydrolysis phase of anaerobic digestion.

During a laboratory-scale, two-phase anaerobic digestion study, Kaseng et al. (1992) observed higher enzymatic activities in the methane phase reactors. The carryover of acidogens from the acid phase reactors resulted in a release of cellular material, which includes extracellular hydrolases (Kaseng et al. 1992). Therefore, the authors 
proposed that the change in enzymatic activity was the result of acidogen destruction as opposed to methanogen activity.

A laboratory-scale, batch aerobic and anaerobic digestion analysis was performed by Rust (1998) in an attempt to correlate protein and polysaccharide release to enzymatic activity. The author observed an accumulation of soluble polysaccharides during aerobic digestion when glucosidase activity was low. An accumulation of soluble proteins was observed during anaerobic digestion when peptidase activity was low (Rust 1998).

\subsection{Temperature Phased Anaerobic Digestion}

\subsubsection{Process}

Temperature phased anaerobic digestion (TPAD) is a two-phase anaerobic digestion system with a short thermophilic $\left(55^{\circ} \mathrm{C}\right)$ phase followed by an extended mesophilic $\left(35^{\circ} \mathrm{C}\right)$ phase. The U.S. version of this system is typically designed with a thermophilic solids retention time (SRT) of 3-5 days followed by a mesophilic SRT of approximately 10 days (Han and Dague 1997). The German version, anaerobic stabilization thermophilic/mesophilic (ASTM), is typically designed with a thermophilic SRT of 2-3 days and a mesophilic SRT of 12-15 days (Oles et al. 1997).

\subsubsection{History}

The ASTM system was developed in Germany and has been implemented at both small and large-scale plants in Europe. The first ASTM was constructed in 1987 in the City of Osterode (Mitsdorffer et al. 1990) and as of 1997, has since been applied to an additional 10 wastewater treatment facilities in Germany (Oles et al. 1997).

In the United States, the TPAD process has recently become a prevalent stabilization method due to changes in federal and state regulations pertaining to the land application of sewerage sludges. Richard Dague (deceased) and co-workers at Iowa State University developed the TPAD process during the early to mid 1990's and obtained a patent in June of 1996 (Han et al. 1997). As a result of this work, a variety of benchscale studies have been performed, several new facilities have been constructed, and a number of existing facilities have been retrofitted to perform TPAD in the U.S. 


\subsubsection{Advantages}

The TPAD system offers the advantages of thermophilic digestion (higher rates of volatile solids (VS) and pathogen destruction, reduced foaming) and mesophilic digestion (less odorous digested sludge) while avoiding the disadvantages (odors associated with thermophilic digestion and low rate solids destruction associated with mesophilic digestion) (Han and Dague 1997). Compared to single-stage mesophilic digestion, the monetary benefits of the TPAD process is a lower initial cost for sludge storage facilities as well as lower annual O\&M costs (Hagley 1998). The capacity to produce Class A biosolids (Huyard et al. 1999) maximizes the ultimate disposal options. By requiring approximately 40 percent less volume than conventional mesophilic digestion, smaller thumbprints are necessary for the system (Han et al. 1997).

\subsubsection{Disadvantages}

The primary disadvantage of the TPAD process is that relatively few full-scale systems exist compared to conventional stabilization methods. The TPAD system is considered an innovative technology (Pincince et al. 1998). Also, the initial capital cost is typically higher for TPAD facilities compared to conventional stabilization methods (Hagley 1998).

\subsubsection{Design Considerations}

Research and full-scale application experience in Germany indicates that successful ASTM application is contingent upon the following parameters: SRT, steadystate temperature, digester mixing, and steady-state feed (Dichtl 1997). As previously discussed, the TPAD system is typically designed with a thermophilic SRT of 1-5 days and a mesophilic SRT of greater than 10 days. At extended thermophilic SRT's, high ammonia concentrations directly associated with high protein degradation by the thermophilic anaerobic bacteria consortia should be taken into account for feed sludges with high protein concentrations (Chao 1999). If the thermophilic SRT is greater than three days, excessive propionate, an intermediate difficult to metabolize to methane, may accumulate in the system (Dichtl 1997). 
Oles et al. (1997) reports that pumping and heat transfer problems may occur (due to viscosity) for feed sludges in excess of six percent. Draft tube mixers (as opposed to gas injection) are recommended for high solids concentration systems. In Europe, concrete or steel, egg-shaped digesters are typically constructed. Thermophilic sludges have a tendency to foam; therefore, overfall weirs inside the reactor and foam traps in the gas lines are recommended.

Heat from the thermophilic sludge is typically recovered via heat exchangers to optimize efficiency. Insulation (energy cost) and fixed covers (odors) on the thermophilic reactors are also recommended (Streeter et al. 1997).

\subsubsection{Research}

\section{Primary Sludges}

Han and Dauge (1997) compared the performance of lab-scale, semi-continuous, primary sludge fed TPAD systems with conventional single-stage mesophilic digestion in terms of coliform reduction, VS destruction and biogas production. Almost complete destruction of total and fecal coliforms were observed, meeting U.S. federal requirements for Class A sludge designation, over an SRT range of 10-15 days was observed with the TPAD system. Compared to the conventional mesophilic system, VS destruction was 18 $\%$ higher and methane production was $16 \%$ higher.

\section{Mixed Sludges}

Han et al. (1997) compared the performance of lab-scale, semi-continuous, mixed sludge (50\% primary, $50 \%$ WAS) fed TPAD systems with single-stage mesophilic digestion in terms of coliform reduction, VS destruction and biogas production. Based on coliform requirements, a Class A sludge was produced with a 11 to 28 day SRT. With a TPAD system volume of approximately $40 \%$ less than the single-stage mesophilic digestion system, the VS destruction at the concluded optimum SRT of 11-17 days was doubled. High VFA concentrations produced during the thermophilic phase were significantly reduced during mesophilic digestion, leading to a less odorous sludge and increased methane production. Foaming, a problem typically observed during the anaerobic digestion of waste activated sludges, was not observed. 
The effect of organic and solids (total and volatile) loading was examined by Vandeburg and Ellis (1999) in lab-scale TPAD systems. It was concluded that VS destruction was only slightly impacted by higher feed VS concentrations; destruction remained above $50 \%$ up to a total solids (TS) feed sludge concentration of approximately $8 \%$. Fecal coliform destruction was not affected by feed VS concentration and over twothirds of the VS destruction occurred during the thermophilic phase of digestion. The mesophilic phase served as a polishing stage to reduce intermediate byproducts produced during thermophilic digestion. Un-ionized ammonia concentrations were tolerated up to $326 \mathrm{mg} / \mathrm{L}$, significantly above the inhibitory levels reported in literature, during the thermophilic phase of digestion which lead to speculation that the TPAD may be useful for the treatment of sludges with high nitrogen concentrations.

To obtain a Process to Further Reduce Pathogens (PFRP) equivalency recommendation, Huyard et al. (1999) spiked a semi-continuous (4 times/day), pilot-scale TPAD system with pathogens at the Belmont AWT facility in Indianapolis, Indiana. The system was spiked with enteric viruses and helminth ova (not present in raw sludge) and a pathogenic organism balance (Fecal coliforms) was performed to demonstrate that the time/temperature conditions would consistently produce Class A biosolids. The system achieved log destruction rates of 5.5, 4.0, and 2.6 for Fecal Coliform, Poliomyelitis Virus and viable Ascaris Suum ova respectively which exceeds the U.S. EPA Pathogen Equivalency Committee elimination requirements. Increased biogas production (compared to the existing single-stage mesophilic system) and a $61 \%$ reduction in VS was also observed. At the time of this publication, the authors expected that a PFRP equivalency status would be granted for the system.

A lab-scale study was conducted by Gabb et al. (1999) to compare the pathogen destruction capabilities of a TPAD system (thermophilic phase only) and a single-stage thermophilic system. Three temperature variations $\left(40^{\circ} \mathrm{C}, 45^{\circ} \mathrm{C}, 55^{\circ} \mathrm{C}\right)$ were evaluated against a mesophilic control of $35^{\circ} \mathrm{C}$. In terms of pathogen destruction, the following was concluded: a 2 day SRT at $50^{\circ} \mathrm{C}$ was equivalent to a 15 day SRT at $45^{\circ} \mathrm{C} ; 2$ day SRT at $55^{\circ} \mathrm{C}$ was equivalent to a 15 day SRT at $45^{\circ} \mathrm{C}$ or $50^{\circ} \mathrm{C}$. U.S. EPA Class A requirements were met for the TPAD system operated at $50^{\circ} \mathrm{C}$ and $55^{\circ} \mathrm{C}$ and the singlestage thermophilic system operated at $45^{\circ} \mathrm{C}, 50^{\circ} \mathrm{C}$, and $55^{\circ} \mathrm{C}$. 
Ghosh et al. (1999) studied the effect of $\mathrm{pH}$, temperature and HRT on mesophilic and thermophilic acidogenesis on mixed sludges (primary/activated). The following system variations were evaluated: temperatures of $35^{\circ} \mathrm{C}$ and $55^{\circ} \mathrm{C}$, pH's of $7,6,5.5$ and 5, and HRT's of 2 and 1.3 days. Carbohydrate, protein, lipid, and $\mathrm{CCPL}$ (sum of the masses of CPL) reductions were accepted as measures of biosolids hydrolytic efficiency because these three major biopolymers accounted for up to about $90 \%$ of the sludge VS (organic matter). VFA production was accepted as a measure of acidification efficiency. The system $\mathrm{pH}$ had the strongest effect on carbohydrate conversion. Hydrolytic activity was higher at a $\mathrm{pH}$ of 7 and temperature of $55^{\circ} \mathrm{C}$ than a $\mathrm{pH}$ of 5 and a temperature of $35^{\circ} \mathrm{C}$. Protein hydrolysis was higher at thermophilic temperatures. Lipid conversion rates increased with increasing $\mathrm{pH}$ and SRT. Temperature had the smallest effect on the acidogenic degradation of proteins. The optimum mesophilic range for $\mathrm{pH}$ was 5.5 to 6 and the optimum thermophilic $\mathrm{pH}$ was approximately 6. Maximum VFA production occurred at a pH of 5.5 (mesophilic) and 6 (thermophilic).

\section{Industrial Sludges}

A bench scale study was conducted by Chao et al. (1999) to determine the performance of a semi-continuous (8 times/day) TPAD system on sludges with high cellular content (50\% domestic, $50 \%$ pulp and paper industry) from the Western Lake Superior Sanitary District TP in Duluth, MN. Various thermophilic/mesophilic SRT combinations were examined (2.5 day/7.5 day, 3/9, 5/15). At an SRT greater than 2.5 days, almost complete destruction of total and fecal coliforms were observed. It was also concluded that the thermophilic SRT had a dramatic influence on VS removal. The optimum configuration was determined to be a thermophilic SRT of 3-5 days followed by a mesophilic SRT of greater than 9 days.

Welper et al. (1997) studied the performance of temperature-phased, anaerobic sequencing batch reactor (ASBR) systems on the treatment of high-strength industrial wastewaters. The lab-scale system (6 hour thermophilic, 12 hour mesophilic) was capable of soluble and total COD removal greater than $95 \%$ and $90 \%$ respectively for COD loads up to $22 \mathrm{~g} / \mathrm{L} /$ day at an HRT of 18 hours. The development and retention of rapidly settling biomass was observed in both the thermophilic and mesophlic system. 
Zhao and Kugel (1996) investigated the performance of the ASTM process for treating a mixture of sewerage sludge and high strength food processing organic waste. The German pilot scale system consisted of a thermophilic $\left(75^{\circ} \mathrm{C}\right)$ phase with an SRT of 2.5 days followed by a mesophilic $\left(37^{\circ} \mathrm{C}\right)$ phase with an SRT of 10 days. High strength organic wastes had some effects on $\mathrm{pH}$, TS and VS removals, VFA and bicarbonate alkalinity. However, these effects were not significant and it was concluded that the ASTM process is effective for treating sewerage sludges combined with high strength organic wastes. The retrofit of two existing digesters with heat provided from a submerged combustion burner led to an increase in gas production and a surplus of thermal energy (Kugel et al. 1992).

Synthetic Substrate

Kaiser et al. (1995) conducted studies on a lab-scale temperature-phased anaerobic biofilter (TPAB) system fed synthetic milk substrate (2-16 g COD/L/day). The set-up consisted of a thermophilic HRT of 3, 4.5, and 6 hours with a system SRT of 24, 36 and 48 hours. The TPAB process achieved soluble and total COD reductions of $97 \%$ and $90 \%$ respectively.

\subsubsection{Full-Scale Systems}

Vik and Olsen (1997) report that the Sturgeon Bay Utilities conversion of an existing single-stage mesophilic digestion system to a TPAD system has been very successful. Plant operators report that the capacity of the digestion process has increased by a factor of two and dewatering properties have improved when compared to the previous mesophilic system. The system has produced Class A biosolids (Coliforms) and an increase of $22 \%$ in VS destruction has been observed. The system is stable, handling large loading and temperature variations. Biogas production has increased while odors have remained the same. A beneficial reuse strategy has been implemented for local nurseries, landscapers and residents (Hinterhuer 1998).

Streeter et al. (1997) reports that the Newton, Iowa, WWTP retrofit of an existing two-stage mesophilic digestion system to a TPAD system has achieved better performance than the lab-scale system used during design. The TPAD system has been very stable, handling shock loads while producing Class A biosolids. The success of the 
Newton WWTP has led the City of Independence, Iowa, to implement the TPAD process. Hunn (1999) reports that the Independence WWTP has retrofitted existing egg-shaped digesters leading to increased gas production and increased solids destruction leading to the production of Class A biosolids.

\subsection{References}

Breure, AM; Mooijman, KA; van Andel, JG (1986) Protein degradation in anaerobic digestion: influence of volatile fatty acids and carbohydrates on hydrolysis and acidogenic fermentation of gelatin. Applied Microbiology and Biotechnology, 24, p 426-431.

Chao, SM; Ellis, TG; Sung, S; Ekola, T.L. (1999) Temperature-Phased Anaerobic Digestion of Waste Activated Sludge from Pulp and Paper Wastewater Treatment. Proceedings of the Water Environment Federation $72^{\text {th }}$ Annual Conference and Exposition, New Orleans, LA, October 9-13, CD.

Cofner, DR; Logan, BE (1997a) Molecular weight distribution of hydrolysis products during biodegradation of model macromolecules in suspended and biofilm cultures I. Bovine Serum Albumin. Water Research, 31(9), p 2127-2136.

Cofner, DR; Logan, BE (1997b) Molecular weight distribution of hydrolysis products during biodegradation of model macromolecules in suspended and biofilm cultures II. Dextran and Dextrin. Water Research, 31(9), p 2137-2145.

Dichtl, N (1997) Thermophilic and mesophilic (two-stage) anaerobic digestion. Water and Environmental Management: Journal of CIWEM, 11(2), p 98-104.

Frolund, B; Griebe, T; Nielsen, PH (1995) Enzymatic activity in the activated-sludge floc matrix. Applied Microbiology and Technology, 43, p 755-761.

Gabb, DMD; Jenkins, D; Ghosh, S; Hake, JM; De Leon, C; Williams, D.R. (1999) Pathogen Destruction Efficiency in High Temperature Anaerobic Digestion. Proceedings of the Water Environment Federation $72^{\text {th }}$ Annual Conference and Exposition, New Orleans, LA, October 9-13, CD.

Gonzales, T; Robert-Baudouy, J (1996) Bacteria aminopeptidases: proteins and functions. FEMS Microbiology Reviews, 18, 319-344.

Ghosh, S; Henry, M.P; Sajjad, A. (1999) Effects of Process-Control Parameters on Hydrolysis \& Acidogenesis of Biosolids. Proceedings of the Water Environment Federation $72^{\text {th }}$ Annual Conference and Exposition, New Orleans, LA, October 913, CD.

Grady, CPL; Daigger, GT; Lim, HC (1998) Biological Wastewater Treatment, $2^{\text {nd }}$ edition, Marcell Dekker, Inc., New York, NY.

Hagley, J (1998) Temperature-phased anaerobic digestion: a cost effective alternative. $12^{\text {th }}$ Annual Residuals and Biosolids Management Conference, Bellevue, Wahsington, July 12-15, p 211-219.

Han, Y; Dague, RR (1997) Laboratory studies on the temperature phased anaerobic digestion of domestic primary sludge. Water Environment Research, 69, p 11391143.

Han, Y; Sung, S; Dague, RR (1997) Temperature-phased anaerobic digestion of 
wastewater sludges. Water Science and Technology, 36(6/7), p 367-374.

Higgins, M; Novak, JT (1997a) The effect of cations on the settling and dewatering of activated sludges: laboratory results. Water Environment Research, 69(2), p 215224.

Higgins, M; Novak, JT (1997b) Dewatering and settling of activated sludges: the case for using cation analysis. Water Environment Research, 69(2), p 225-232.

Higgins, M; Novak, JT (1997c) Characterization of exocellular protein and its role in bioflocculation. Journal of Environmental Engineering, 123(5), p 479-485.

Hinterhuer, H (1998) Sturgeon Bay adopts biosolids beneficial reuse strategy. Water/Engineering Management, 145(1), p 20-23.

Horan, NJ; Eccles, CR (1986) Purification and characterization of extracellular polysaccharide from activated sludges. Water Research, 20(11), p 1427-1432.

Hunn, T (1999) TPAD Improves Biosolids Quality. Water Environment and Technology, 11(3), p 24-25.

Huyard, A; Ferran, B; Audic, J.M.; Dieterlen, J; Adamick, J; Noel, T. (1999) Spiking a Two Phase Anaerobic Digestion Pilot Plant: An Innovative Approach to Obtain a P.F.R.P. Equivalency Recommendation. Proceedings of the Water Environment Federation $72^{\text {th }}$ Annual Conference and Exposition, New Orleans, LA, October 913, CD.

Jackson-Moss, CA; Duncan, JR (1990) The effect of iron on anaerobic digestion. Biotechnology Letters, 12(2), p 149-154.

Kaiser, SK and Dauge, RR (1995) Initial studies on the temperature-phased anaerobic biofilter process. Water Environ. Res. 67(7), 1095-1103.

Kaseng, K; Ibrahim, K; Paneerselvam, SV; Hassan, RS (1992) Extracellular enzymes and acidogenic profiles of laboratory-scale two-phase anaerobic digestion system. Process Biochemistry, 27(1), p 43-47.

Kugel, G; Zingler, E; Hellfeier, G. (1992) Upgrading of 100,000 PE Goch sewage treatement plant - design of a 2-stage sewage treatment and anaerobic thermophilic/mesophilic sludge stabilization. Wat. Sci. Tech., 25(4/5), 331-337.

Madigan MT; Martinko JM, Parker, J (1997) Brock Biology of Microorganisms, $8^{\text {th }}$ edition. Prentice Hall, Upper Saddle River, NJ.

Metcalf and Eddy, Inc. (1991) Wastewater Engineering: Treatment, Disposal, and Reuse, $3^{\text {rd }}$ edition. McGraw Hill Inc., New York, NY.

Mitsdorffer, R; Demharter, W; Bischofsberger, W; (1990) Stabilization and disinfection of sewage sludge by two-stage anaerobic thermophilic/mesophilic digestion. Water Science and Technology, 22(7/8), p 289-298.

Morgan, JW; Forster, CF, Evison, L (1990) A comparative study of the nature of biopolymers extracted from anaerobic and activated sludges. Water Research, 24(6), p 743-750.

Murthy, SN; Novak, JT (1999) Factors Affecting Floc Properties During Aerobic Digestion: Implications for Dewatering. Water Environment Research. 71(2), p 197-202.

Murthy, SN; Novak, JT (1998) Effects of potassium ion on sludge settling, dewatering and effluent properties. Wat. Sci. Tech., 37(4-5), p 317-324.

Murthy, SN; Novak, JT; De Hass, D (1998) Monitoring cations to predict and improve sludge settling and dewatering properties of industrial wastewater. Wat. Sci. 
Tech., 38(3), p 119-126.

Novak, JT; Becker, H; Zurow, A (1977) Factors influencing activated sludge properties. Journal of the Environmental Engineering Division, 103(EE5), 815-828.

Novak, JT; Goodman, GL; Pariroo, A; Huang, JC (1988) The blinding of sludges during filtration. Journal WPCF, 60(2), p 206-214.

Novak, JT; Love, NG; Smith, ML; Wheeler, ER (1998) The effect of cationic salt addition on the settling and dewatering properties of industrial activated sludge. Water Environment Research, 70(5), p 984-996.

Nybroe, O; Jorgensen, PE; Henze, M (1992) Enzyme activities in wastewater and activated sludge. Water Research, 26(5), 579-584.

Oles, J; Dichtl, N; Niehoff, HH (1997) Full scale experience of two stage thermophilic/mesophilic sludge digestion. Water Science and Technology, 36(6/7), p 449-456.

Pincince, A.B; Moss, LH; Donovan, JF; Switzenbaum, MS (1998) Biosolids Management: Evaluation of Innovative Processes, Water Environment Research Foundation, Project 96-REM-1, Alexandria, VA, p 4-16.

Poxon, TL; Darby, JL (1997) Extracellular polyanions in digested sludge: measurement and relationship to sludge dewaterability. Water Research, 31(4), p 749-758.

Rasmussen, H; Nielsen, P.H. (1996) Iron reduction in activated sludge measured with different extraction techniques. WaterResearch, 30(3), p 551-558.

Rust, ME (1998) Biopolymer and cationic release in aerobic and anaerobic digestion and the consequent impact on sludge dewatering and conditioning properties. M.S. Thesis, VPI \& SU, Blacksburg, VA.

Streeter, M; Dague, RR; Main, RE (1997) Evaluation of field application, temperature phased anaerobic digestion. Proceedings of the Water Environment Federation $70^{\text {th }}$ Annual Conference and Exposition, Chicago, Illinois, October 18-22, p 181191.

Vandenburgh, S.R; Ellis, T.G. (1999) Effect of Varying Solids Concentration and Organic Loading on the Performance of TPAD to Produce Class A Biosolids. Proceedings of the Water Environment Federation $72^{\text {th }}$ Annual Conference and Exposition, New Orleans, LA, October 9-13, CD.

Vik, T; Olsen, C (1997) Full scale operation of temperature-phased anaerobic digestion. Proceedings of the Water Environment Federation $70^{\text {th }}$ Annual Conference and Exposition, Chicago, Illinois, October 18-22, p 139-146.

Warren, LA; Ferris, FG (1998) Continuum between sorption and precipitation of Fe(III) on microbial surfaces. Water Science and Technology, 32, p 2331-2337.

Welper, LL; Sung, S; Dague, RR (1997) Laboratory studies on the temperature-phased ASBR system. Water Science and Technology, 36(2/3), p 295-302.

Zhao, Q; Kugel, G (1996) Thermophilic/mesophilic digestion of sewage sludge and organic wastes. Journal of Environmental Science and Health, A31(9), p 22112231. 


\section{MANUSCRIPT}

The following manuscript was submitted to Water Environment Research for

editorial review. The manuscript is based on a paper in the proceedings of WEFTEC 2000. 


\title{
CHANGES IN DEWATERING PROPERTIES BETWEEN THE THERMOPHILIC AND MESOPHILIC STAGES IN TPAD SYSTEMS
}

\author{
Jason L. Bivins and John T. Novak \\ Virginia Polytechnic Institute \& State University \\ 418 New Engineering Building \\ Blacksburg, Virginia 24061
}

\begin{abstract}
Temperature-phased anaerobic digestion (TPAD) has become increasingly appealing in recent years due to the pathogen destruction capabilities of the system. However, there has also been concern about the dewatering properties of the sludges created by these systems. A laboratory study was conducted at Virginia Tech to determine the effect of thermophilic solids retention time (SRT) on sludge dewatering properties, to characterize system parameters associated with dewatering, and to understand the mechanisms causing changes in dewatering properties between the thermophilic and mesophilic phases. The study showed that while anaerobic digestion caused dewatering properties to deteriorate, sludges varied little with thermophilic SRT. Acidogenesis was essentially complete after 1.5 days. Subsequent mesophilic digestion resulted in little change to dewatering properties and modest reductions in conditioning doses, but substantial reductions in biopolymer (protein + polysaccharides) occurred. It appears that thermophilic anaerobic digestion creates or releases colloidal materials that cause dewatering to be poor and subsequent mesophilic digestion for 15 days does little to improve sludge properties of TPAD systems.
\end{abstract}

\section{KEYWORDS}

Thermophilic, mesophilic, anaerobic digestion, dewatering, conditioning, biopolymer

\section{INTRODUCTION}

Prior to 1992, technology and process based standards governed the land application of sewage sludges. New regulations pertaining to land application mandate higher pathogen destruction requirements than are typically feasible with conventional anaerobic digesters operated at mesophilic temperatures (typically $35^{\circ} \mathrm{C}$ ). These higher standards, often referred to as Class A biosolids, are defined within U.S. EPA 40 CFR Part 503 Standards for the Use and Disposal of Sewage Sludge. Many wastewater treatment facilities do not have access to the site restricted land application areas required for Class B sludges. Approximately 40 percent of all municipal sewage sludges are currently land applied or marketed to proprietary organizations (Stukenberg et al. 1992). Therefore, the impact of these regulations has been and will continue to be substantial. The capacity to produce Class A biosolids maximizes the ultimate disposal options of biosolids by wastewater treatment facilities. 
For decades, conventional anaerobic digestion (single-stage/mesophilic) has been the standard for sludge stabilization in large-scale municipal wastewater treatment plants. The rate limiting steps associated with anaerobic digestion are hydrolysis and methanogenesis. The goal of the two-phase system, introduced in the 1970's, was to optimize the environments for specific biological reactions by confining hydrolysis and acidogenesis to a single bioreactor, while allowing acetogenesis and methanogenesis to occur in a second reactor in series (Ghosh 1987). Advantages of the two-phase system include increased sludge stabilization and gasification as well as improved process stability. However, some studies have suggested that the increase in efficiency does not necessarily justify the increased operational cost of the two-phase anaerobic digestion system (Bhattacharya et al 1996). Thermophilic (typically $55^{\circ} \mathrm{C}$ ) digesters were studied in single-phase (Garber 1977) and two-phase configurations (Lee et al. 1989). Higher pathogen destruction at shorter solids retention times was observed in both systems than typically occur in conventional mesophilic digestion systems. However, high volatile fatty acid concentrations, leading to lower process stability and odor problems, made this system less appealing.

Several configurations have been proposed that combine both thermophilic and mesophilic digestion. The DuPage 2-phase digestion system consists of a mesophilic phase (1.5 days) followed by a thermophilic phase (10 days) in series (Wilson 1998). The thermophilic phase achieves pathogen destruction to enable Class A sludge classification. Aeration may be required after thermophilic digestion for sludge polishing and deodorization (Forbes and Wooley 1998).

The Anaerobic Stabilization Thermophilic/Mesophilic (ASTM) system was developed in Germany and has been implemented at both small and large scale plants in Europe. This system consists of a thermophilic phase (2-5 day SRT) followed by a mesophilic phase (10-15 day SRT) (Oles et at. 1997). The U.S version of this system, Temperature Phased Anaerobic Digestion (TPAD), was developed (early 1990's) and patented (June 1996) by Richard Dague and coworkers at Iowa State University (Han and Dague 1998). The ASTM and TPAD systems are very similar and will be discussed as equivalents. The system described in this study will be referred to as a TPAD system for convenience. Many of the problems associated with single and two-phase, mesophilic or thermophilic digestion systems are overcome by the TPAD configuration. High concentrations of VFA's are created during thermophilic digestion; however, VFA's are greatly reduced during mesophilic digestion, enabling greater process stability. Due to high VFA concentrations, the thermophilic phase of this system is still odorous; however, fixed covers on the thermophilic digesters can alleviate this problem (Wilson and Dichtl 1998). Most importantly, Class A biosolids can be achieved by this system at reasonable SRT's due to the high pathogen destruction in the thermophilic phase (Streeter et al. 1997).

One concern about the TPAD system and other thermophilic anaerobic processes is that the dewatering properties of the digested biosolids may be difficult and expensive to dewater. Rust (1998) found that increased temperatures resulted in higher capillary suction times (CST), increases in polymer conditioning requirements, and higher 
biopolymer concentrations in solution. The increase in polymer conditioning requirements was attributed to the release of biopolymer (protein and polysaccharides) into solution and the biopolymer concentration increased with both temperature and digestion time.

\section{Objectives}

In the study, a laboratory TPAD system was operated to investigate the changes that occurred in both the thermophilic and mesophilic phases and specifically to determine the impact of the thermophilic SRT on sludge dewatering properties. A second important aspect of this study was to determine the effect of mesophilic digestion on sludge dewatering properties.

\section{METHODS AND MATERIALS}

A laboratory scale, semi-continuous TPAD system was maintained at different solids retention times (1.5, 2, 2.5, and 3 days) while the mesophilic SRT was the same (15 days) for four set-ups. Operational parameters monitored included: $\mathrm{pH}$, filterable COD, total solids, ammonium ion, filterable anions and filterable volatile fatty acids. In an attempt to characterize the dewatering properties of the system, the following parameters were monitored: filterable proteins and polysaccharides, leucine-aminopeptidase activity, filterable cations, filterable and total iron, CST and conditioning requirements. A particle size distribution analysis was performed to characterize filterable biopolymer and COD.

The filterable fraction of each parameter investigated was assumed to be confined to the supernatant that could be filtered through a $1.5 \mu \mathrm{m}$ filter. The fraction of material contained within the $1.5 \mu \mathrm{m}$ to $30 \mathrm{~K}$ AMU size range was regarded as the colloidal size fraction. The error bars on each graph represents \pm one standard deviation.

The experimental system consisted of two completely mixed reactors in series, a thermophilic phase followed by a mesophilic phase. A description of the system configuration is provided in Table 1. The system was operated in a semi-continuous manner by feeding and withdrawing sludge every 12 hours via peristaltic pumps. Exogenous buffers for $\mathrm{pH}$ were not required as the $\mathrm{pH}$ remained approximately neutral in both phases of digestion. The solids and hydraulic retention times (SRT and HRT) were equal. Recycled activated sludge (RAS) was used as the feed to the thermophilic reactors. This sludge was obtained from the Blacksburg-VPI Sanitation Authority, Lower Stroubles Creek WWTP. The plant has recently been retrofitted for biological nutrient removal; an anaerobic zone exists in the activated sludge basin. The RAS was decanted to a total solids concentration of $1.5 \pm 0.1$ percent and stored up to one week at $4^{\circ} \mathrm{C}$ in carboys.

After operation for three SRT's to approximate steady state, the reactors were sampled every 12 hours during the periods of sludge feed and withdrawal. Each sample was 
filtered through a $1.5 \mu \mathrm{m}$ glass filter prior to storage. Non-acidified samples were frozen and acidified samples were stored at $4^{\circ} \mathrm{C}$ at a $\mathrm{pH}$ of $<2$.

Protein concentration was measured using the Hartree (1972) modification of the Lowry et al. (1951) method. Polysaccharide was measured using the Dubois et al. (1956) method. Bovine serum albumin and glucose served as the standards for the protein and polysaccharide analysis, respectively. An assay for leucine-aminopeptidase was performed using L-leucine-p-nitroanilide as described by Murthy and Novak (1999).

Filterable cations were analyzed with a Dionex (DX120) Ion Chromatograph containing a CS12 column and conductivity detector (Dionex 2010X) with a self-generating suppression of the eluent. The eluent, methane sulfonic acid at $20 \mathrm{mM}$, ran at a flow rate of $1.0 \mathrm{~mL} / \mathrm{min}$. The following cations were quantified: sodium, ammonium, potassium, magnesium, and calcium. Filterable anions, sulfate and phosphate, were measured using a Dionex Ion Chromatograph with an AS4A-SC column and conductivity detector with a self-generating suppression of eluent. A mix of sodium bicarbonate $(1.7 \mathrm{mM})$ and sodium carbonate $(1.8 \mathrm{mM})$ was used as the eluent at a flow rate of $2 \mathrm{ml} / \mathrm{min}$.

Filterable COD concentrations were determined using Method 5220C of Standard Methods (1995). Method 3111B of Standard Methods (1995) was used to quantify filterable iron. Total iron concentrations were determined using EPA Method 3050 (Acid Digestion of Sediments, Sludges, and Soils). Total solids measurements were obtained by method 2540B of Standard Methods (1995). Volatile Fatty Acid (VFA) concentrations were measured with a Hewlett Packard 5880 Gas Chromatograph fitted with a flame ionization detector. The following VFA's were analyzed: acetate, propionate, butyrate, and valerate.

Particle size distributions were established by filtering samples through a $1.5 \mu \mathrm{m}$ glass filter (Whatmas 934-AH), 30K amu membrane (Amicon YM30), and a $1 \mathrm{~K}$ amu membrane (Amicon YM1). The sludge was conditioned with $100 \mathrm{~g} / \mathrm{L} \mathrm{FeCl}_{3}$ and $0.1 \%$ Nalco 9909, a high strength cationic polymer. The capillary suction time (CST) was determined using Method 2710G of Standard Methods. The conditioning studies were performed with freshly wasted sludge after cooling to room temperature.

\section{RESULTS AND DISCUSSION}

The effect of anaerobic digestion on the dewatering rate for both the thermophilic and mesophilic phases is shown in Figure 1. The CST increased from 15 seconds for the undigested waste activated sludge to values exceeding 700 seconds. As the thermophilic detention time increased, the dewatering became poorer and this continued through the mesophilic phase. Even though the SRT was 15 days for each mesophilic reactor, only a slight improvement in dewatering properties was observed as a result of the mesophilic digestion phase.

The typical conditioning requirement for mesophilically digested sludge is between 2.5 $\mathrm{g} / \mathrm{kg}$ (aerobic) and $5 \mathrm{~g} / \mathrm{kg}$ (anaerobic). The optimum polymer dose was selected to be the 
quantity of polymer required to reduce the CST to 50 seconds. As shown in Figure 2, the optimum polymer dose was on average approximately $83 \mathrm{~g} / \mathrm{kg}$ for the thermophilic phase and approximately $81 \mathrm{~g} / \mathrm{kg}$ for the mesophilic phase of the TPAD system. The polymer conditioning requirement differed little across the thermophilic and mesophilic reactors for all four set-ups. The effect of mesophilic digestion was to lower the average polymer conditioning demand, but the reduction was small. As with the dewatering rate, the longer thermophilic detention time resulted in higher polymer demand. It appears that for the reactor configuration used in this study, thermophilic digestion caused sludges to be much poorer with regard to dewatering and the second phase mesophilic digestion did little to "repair" the sludges.

The greatest changes observed between the thermophilic and mesophilic phases of digestion were in the concentration of filterable COD, protein, and polysaccharides. In Figure 3, the changes in COD, proteins and polysaccharides across the system are shown along with their size-separated concentrations. The reduction in COD between the thermophilic and mesophilic phase appears to be the result of volatile fatty acid (VFA) destruction and the removal, via destruction and/or reflocculation, of protein and polysaccharide from solution. However, the colloidal COD size fraction is approximately the same for both phases of digestion. During this study, it was assumed that the colloidal size fraction consisted of material in the range from $1.5 \mu \mathrm{m}$ to $30 \mathrm{~K}$ amu.

Both the protein and polysaccharide concentrations increase with increasing thermophilic SRT. This would account for the increase in CST and also the increased polymer demand. Novak, et al. (1999) showed that the dewatering properties and polymer demand for digested sludges is dependent upon the solution protein content. Therefore, the increase in protein is expected to be associated with poorer dewatering. It can also be seen from the data in Figure 3 that the majority of filterable protein in the thermophilic reactors is less than $1 \mathrm{~K}$ amu. In fact, the size distribution appears to consist of two major sizes, proteins between $1.5 \mu \mathrm{m}$ and $30 \mathrm{~K}$ amu and the much smaller material less than $1 \mathrm{~K}$ amu. It would be expected that the material in the larger fraction, which can be considered colloidal, would most likely be the material that interferes with filtration of sludges.

The polysaccharides differ from proteins in that they make up a much smaller amount of the filterable material and they consist mostly of material in the range from $1.5 \mu \mathrm{m}$ to $30 \mathrm{~K}$ amu. Degradation of polysaccharides occurs in the mesophilic phase but as with proteins, little of the degraded material comes from the colloidal size range. The majority of protein and polysaccharides that remain after degradation is in the colloidal size range and that most likely accounts for the continued poor dewatering properties of the mesophilically digested sludges, even though the protein content drops considerably.

Sludge conditioning studies were conducted using both polymer and ferric chloride. Both were adequate for conditioning. Figure 4 suggests that the main role of conditioning is to remove colloidal material and that the dewatering properties and conditioning dose can be linked to this specific size fraction. In this investigation, only protein and polysaccharides were quantified. It is likely that other colloidal materials are present and 
these will also contribute to both the resistance to filtration and conditioning chemical dose. In addition, the separation into a "colloidal fraction" using molecular weight suggests that the material contributing to the deterioration in dewatering properties can be better defined.

In order to determine the reason for the accumulation of proteins in the thermophilic reactors, protein degrading enzyme activity was measured using the leucineaminopeptidase activity test. It can be seen in Figure 5 that the activity is lower in the thermophilic reactors and decreases as the thermophilic SRT increases. This explains how proteins accumulate in these systems and how they are degraded in the mesophilic reactors. A similar decrease in enzyme activity was also noted by Rust (1998) for batch digestion systems and the decrease in activity was greatest when the temperature was highest.

Volatile fatty acids, shown in Figure 6, were monitored to gain a better understanding of various process intervals and efficiencies. It was expected that the VFA's would be degraded in the mesophilic reactors so the decline was no surprise and simply indicates that the anaerobic system is working properly. The only major difference associated with thermophilic SRT was a substantial decrease in butyric acid concentration after 1.5 days. It was estimated that approximately 40 percent of the low molecular weight VFA formation can probably be attributed to high molecular weight VFA destruction. Based on the VFA analysis, it appears that acidogenesis is essentially complete within 1.5 days of thermophilic digestion.

The filterable ammonium ion concentration, shown in Figure 7, increased significantly $(+1700 \%)$ during the thermophilic phase of digestion. The concentration of filterable ammonium also increased in the mesophilic reactors $(+18 \%)$. The majority of the increase in filterable ammonium ion concentration can probably be attributed to protein degradation. Novak (In Press) concluded that an increase in ammonium ion in the soluble sludge fraction has an adverse effect on dewatering properties. The increase in ammonium ion concentration in the mesophilic phase of digestion may have counteracted some of the improvements in dewatering properties seen via the reduction of filterable biopolymer.

On average, there was a $580 \mathrm{mg} / \mathrm{L}$ filterable protein difference between the thermophilic and mesophilic phases of digestion. Also, filterable ammonium increased from the thermophilic to mesophilic reactors by $80 \mathrm{mg} / \mathrm{L}$. A mass balance was performed to determine the fate of protein during mesophilic digestion. Based on an average of 20 standard amino acids, it was assumed that there was $1.45{\text { mole } \mathrm{NH}_{3}}^{+} /$mole amino acid and $110 \mathrm{~g}$ protein / mole amino acid. When the decrease in filterable protein and increase in filterable ammonium was considered, it was estimated that $80 \mathrm{mg} / \mathrm{L} \mathrm{NH}_{4}{ }^{+}$is equivalent to $435 \mathrm{mg} / \mathrm{L}$ of degraded protein. There is still $145 \mathrm{mg} / \mathrm{L}$ of filterable protein that is unaccounted for. Therefore, degradation does not account for all of the filterable protein removed from solution during mesophilic digestion. 
As seen in Figure 8, the filterable magnesium concentration decreased by approximately $50 \%$ during mesophilic digestion. Therefore, some of the filterable protein reduction can probably be attributed to reflocculation of protein. The role of magnesium is unclear at this time. However, this research has led to speculation that magnesium may play a role in the reduction of filterable protein during anaerobic digestion, which leads to an improvement in the dewatering properties of TPAD systems. Some of the reduction in filterable magnesium during the mesophilic phase of digestion may have contributed to the colloidal fraction by the formation of inorganic complexes (e.g. struvite), possibly contributing to poor dewatering properties. Although the filterable iron concentration was low, a similar reduction was observed during the mesophilic phase of digestion and may also be attributable to biopolymer reflocculation.

What appears to occur during TPAD with regard to dewatering properties is that colloidal material is generated in the thermophilic phase and the accumulation increases as the thermophilic detention time increases. When the sludge is transferred to the mesophilic reactor, degradation of the filterable protein and polysaccharides occurs but the colloidal fraction is degraded more slowly than the smaller molecular weight fraction. As a result, dewatering properties and conditioning requirements do not improve markedly, even though considerable quantities of COD are converted to gas. What is not known is the reason the colloidal fraction is not degraded. It may be related to the SRT (in this study, only 15 days was investigated), the large amount of smaller molecular weight material, or preferential degradation. Once the smaller material degrades, the colloidal fraction might then be degraded in a sequential manner. It appears that the TPAD system has the potential to cause sludges to deteriorate. The role of the mesophilic system in improving sludges should be further investigated as a means of making these systems more acceptable for producing Class A biosolids.

\section{CONCLUSIONS}

1. Thermophilic anaerobic digestion results in poor sludge dewatering characteristics.

2. The deterioration in dewatering properties appears to be associated with the accumulation of proteins and polysaccharides in colloidal size fraction.

3. The accumulation of protein is associated with lower enzyme activity.

4. Only a small fraction of the colloidal material is removed from solution during the first 15 days of mesophilic digestion.

5. Conditioning of sludges with either polymer or iron salts appear to remove the colloidal protein and polysaccharide size fraction.

6. Mesophilic digestion did not markedly improve dewatering properties after thermophilic digestion. 


\section{AUTHORS}

At the time of this research, Jason L. Bivins was a M.S. candidate in the Department of Civil Engineering, Virginia Polytechnic Institute and State University, Blacksburg, Virginia, and is currently employed at USFilter Kruger Products, Cary, North Carolina. John T. Novak is a professor in the Charles Edward Via, Jr., Department of Civil Engineering, Virginia Polytechnic Institute and State University.

\section{REFERENCES}

Bhattacharya, SK; Farrell, JB; Geron, A (1988) Conventional and two-phase anaerobic digestion of primary and waste activated sludge. Proceedings of the International Conference of Environmental Contamination, Venice, Italy.

Dubois, M, Gilles, K.A., Hamilton, J.K., Rebers, P.A., Smith, F. (1956) Colorimetric Method for Determination of Sugars and Related Substances. Anal. Chem., 28, 350.

Garber, WF (1977) Certain aspects of anaerobic digestion of wastewater solids in the thermophilic range at the Hyperion Treatment Plant. Progresses of Water Technology, 8(6), p 401-406.

Ghosh, S (1987) Improved sludge gasification by two-phase anaerobic digestion. Journal of Environmental Engineering, 113, p 1265-1284.

Han, Y; Dague, RR (1998) Laboratory studies on the temperature-phased anaerobic digestion of mixtures of primary and waste activated sludge. Proceedings of the Water Environment Federation $69^{\text {th }}$ Annual Conference and Exposition, Dallas, Texas, October 5-9, p 83-91.

Hartree, E.F. (1972) Determination of Protein: A Modification of the Lowry Method that Gives a Linear Photometric Response. Anal. Biochem., 48, 422.

Lee, KM; Brunner, CA; Farrel, JB; Eralp, AE (1989) Destruction of enteric bacteria and viruses during two-phase digestion. Journal of Water Pollution Control Federation, 61(8), p 1421-1429.

Lowry, O.H., Rosebrough, N.J., Farr, A.L., Randall, R.J. (1951) Protein Measurement with the Folin Phenol Reagent. J. Biol. Chem., 193, 265.

Murthy, SN; Novak, JT (1999) Factors Affecting Floc Properties During Aerobic Digestion: Implications for Dewatering. Water Environment Research. 71(2), p 197-202.

Novak, J.T. (In Press) The Effect of the Ammonium Ion on Activated Sludge Settling Properties. Water Environment Research. 
Novak, JT; Sadler, ME; Murthy, SN (1999) Mechanisms Influencing Conditioning and Dewatering of Aerobically and Anaerobically Digested Biosolids. Proceedings of the Water Environment Federation Annual Conference and Exposition, New Orleans, LA, CD.

Oles, J; Dichtl, N; Niehoff, HH (1997) Full scale experience of two stage thermophilic /mesophilic sludge digestion. Water Science and Technology, 36(6/7), p 449-456.

Rust, ME (1998) Biopolymer and cationic release in aerobic and anaerobic digestion and the consequent impact on sludge dewatering and conditioning properties. M.S. Thesis, VPI \& SU, Blacksburg, VA.

Standard Methods for the Examination of Water and Wastewater, $19^{\text {th }}$ Ed. (1995). American Public Health Association, Washington, D.C.

Streeter, M; Dague, RR; Main, RE (1997) Evaluation of field application, temperature phased anaerobic digestion. Proceedings of the Water Environment Federation $70^{\text {th }}$ Annual Conference and Exposition, Chicago, Illinois, p 181-191.

Stukenberg, JR; Clark, JH; Shimp, GF; Sandino, J; Crosse, JT (1992) Compliance outlook: meeting the 503 pathogen reduction criteria with anaerobic digestion. Proceedings of the Water Environment $65^{\text {th }}$ Annual Conference and Exposition, New Orleans, LA, p 169-179.

Wilson, TE; Dichtl, NA (1998) Two phase anaerobic digestion: an assesment. Water Environment Federation 12 ${ }^{\text {th }}$ Annual Residuals and Biosolids Management Conference, Bellevue, Washington, July 12-15, p 195-203. 
TABLE 1: Experimental System Configuration

\begin{tabular}{|l|c|c|c|c|c|}
\hline & \multicolumn{4}{|c|}{ Thermophilic Phase } & Mesophilic Phase \\
\hline & T1 & T2 & T3 & T4 & \\
\hline SRT & 1.5 days & 2 days & 2.5 days & 3 days & 15 days \\
\hline Sludge Volume & $750 \mathrm{ml}$ & $1000 \mathrm{ml}$ & $1250 \mathrm{ml}$ & $1500 \mathrm{ml}$ & $5 \mathrm{~L}$ \\
\hline Reactor Volume & \multicolumn{4}{|c|}{$2 \mathrm{~L}$} & $4.5 \mathrm{~L}$ \\
\hline Temperature & \multicolumn{4}{|c|}{$\begin{array}{c}55^{\circ} \mathrm{C}\left( \pm 1^{\circ} \mathrm{C}\right) \\
\text { via water bath }\end{array}$} & $\begin{array}{c}35^{\circ} \mathrm{C}\left( \pm 1^{\circ} \mathrm{C}\right) \\
\text { via water bath }\end{array}$ \\
\hline Mixing & \multicolumn{4}{|c|}{$\begin{array}{c}\text { Shaken via shaker bath } \\
(95 \text { opm })\end{array}$} & $\begin{array}{c}\text { Gear motors/paddles } \\
(100 \mathrm{rpm})\end{array}$ \\
\hline Other Features & \multicolumn{4}{|c|}{ Gas release and sludge feed/withdrawal capabilities } \\
\hline
\end{tabular}


FIGURE 1: Effect of Thermophilic (T) and Mesophilic (M) Anaerobic Digestion On The Dewatering Rate of Waste Activated Sludge

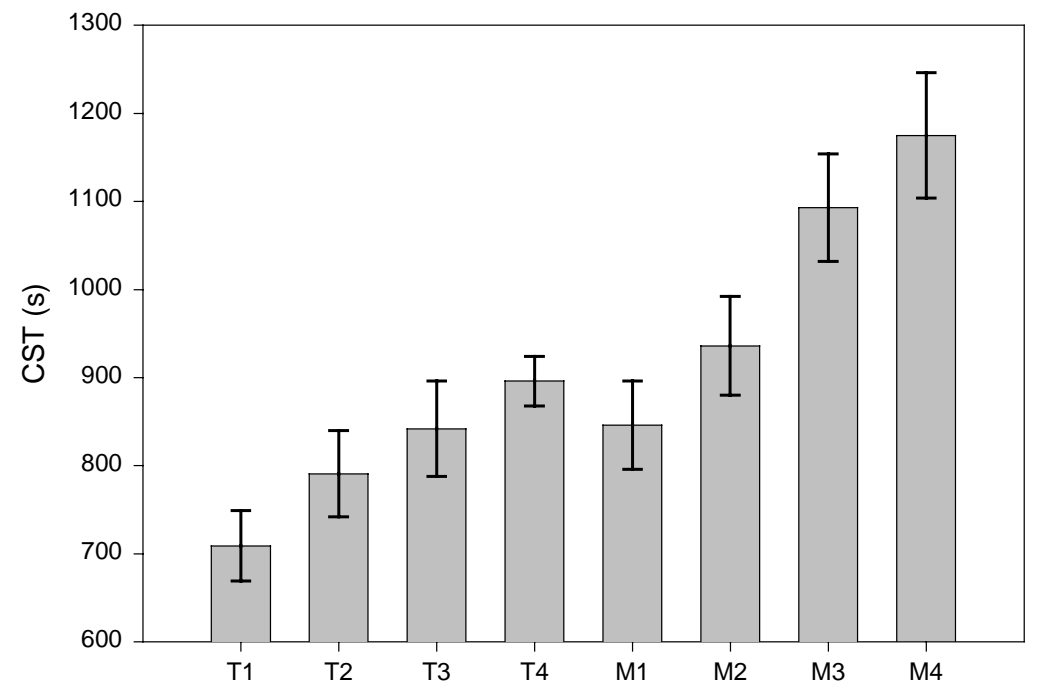


FIGURE 2: Effect Of Thermophilic and Mesophilic Anaerobic Digestion On Polymer Conditioning Chemical Dose Requirements

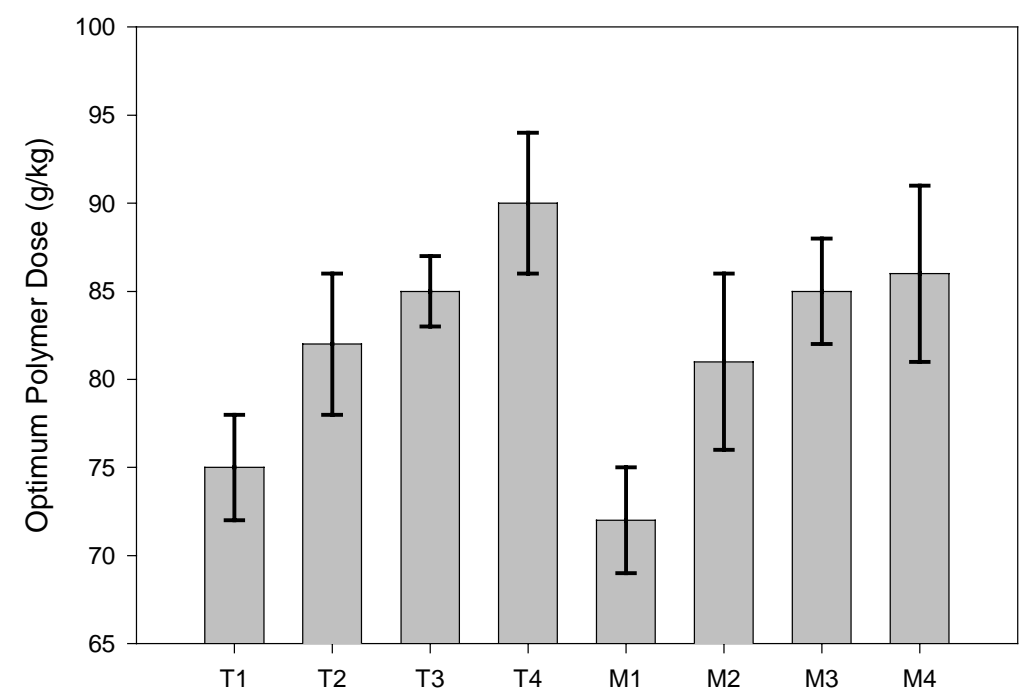


FIGURE 3: Size Distribution of Filterable Protein, Polysaccharides, and COD Across the Digesters

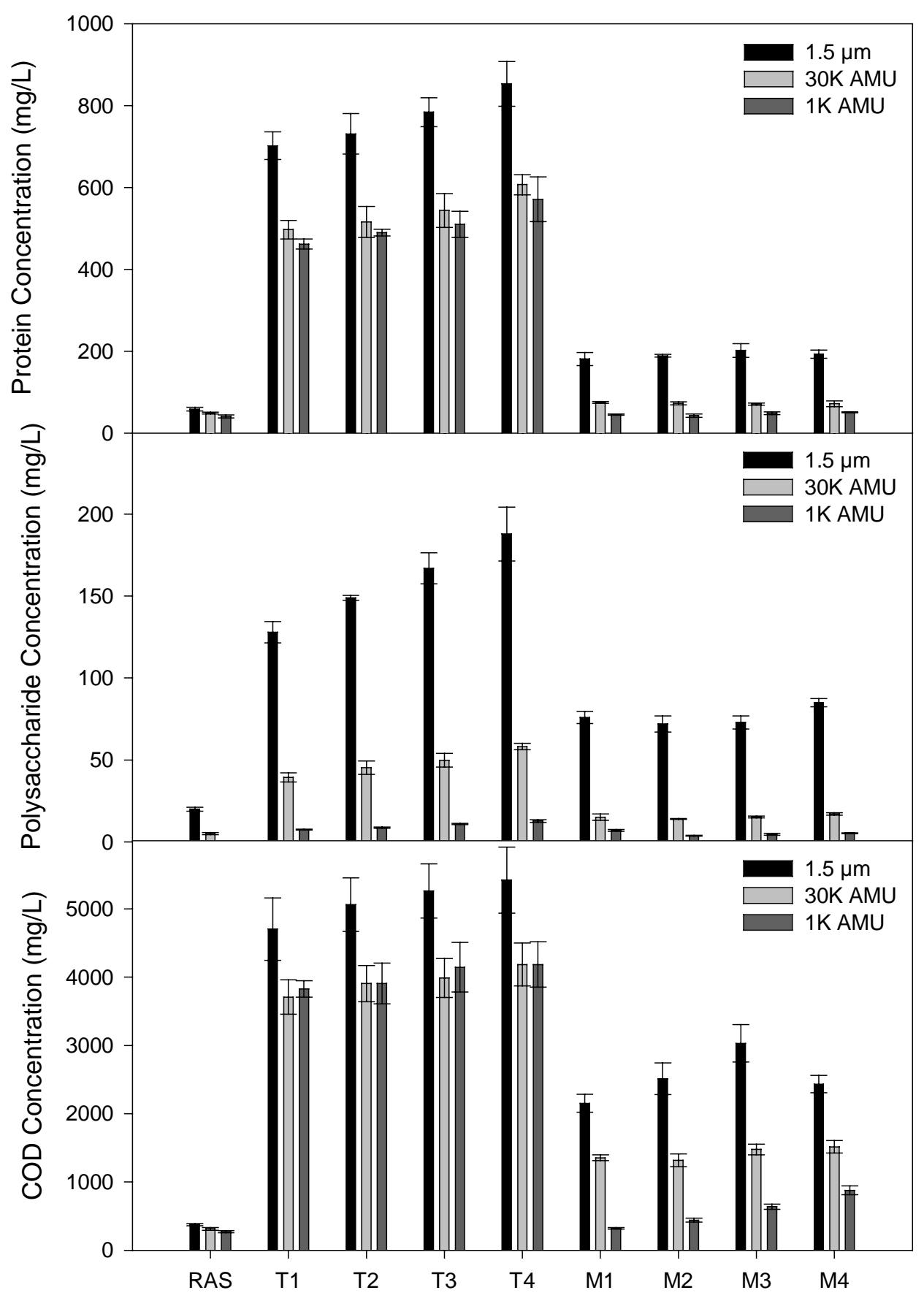


FIGURE 4: Colloidal COD Concentration before Conditioning versus Optimum Polymer Dose Requirement $\left(R^{2}=0.36\right)$

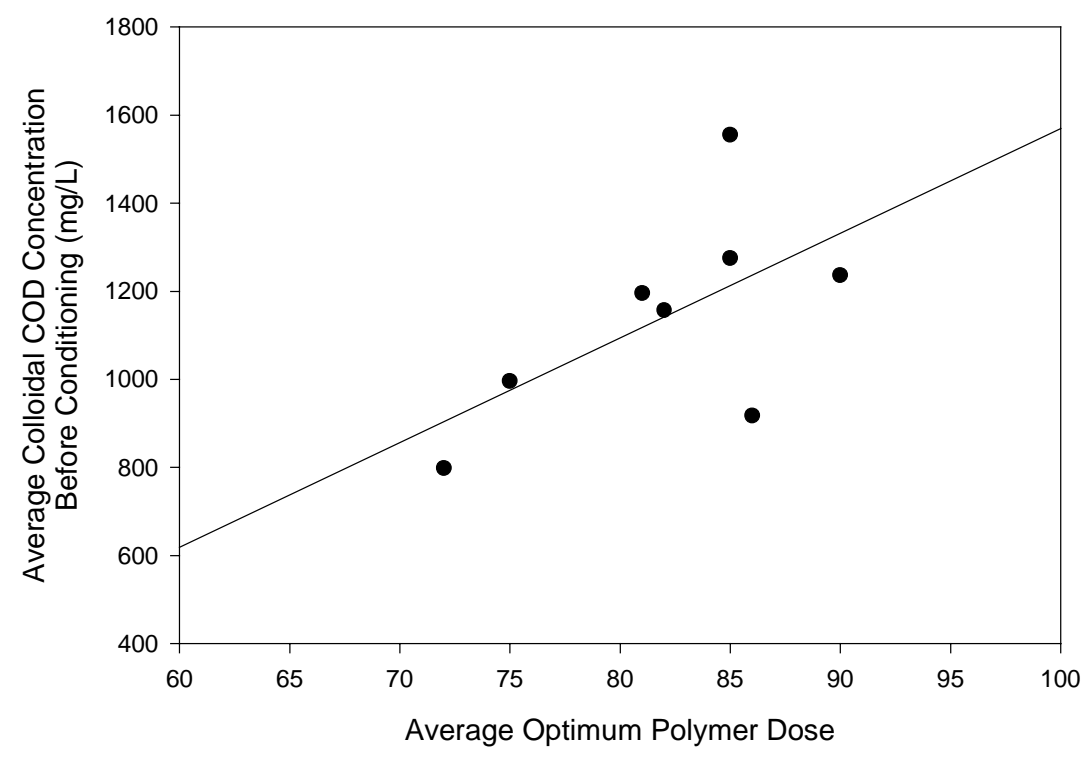


FIGURE 5: Leucine-Aminopeptidase Activity in the Digesters

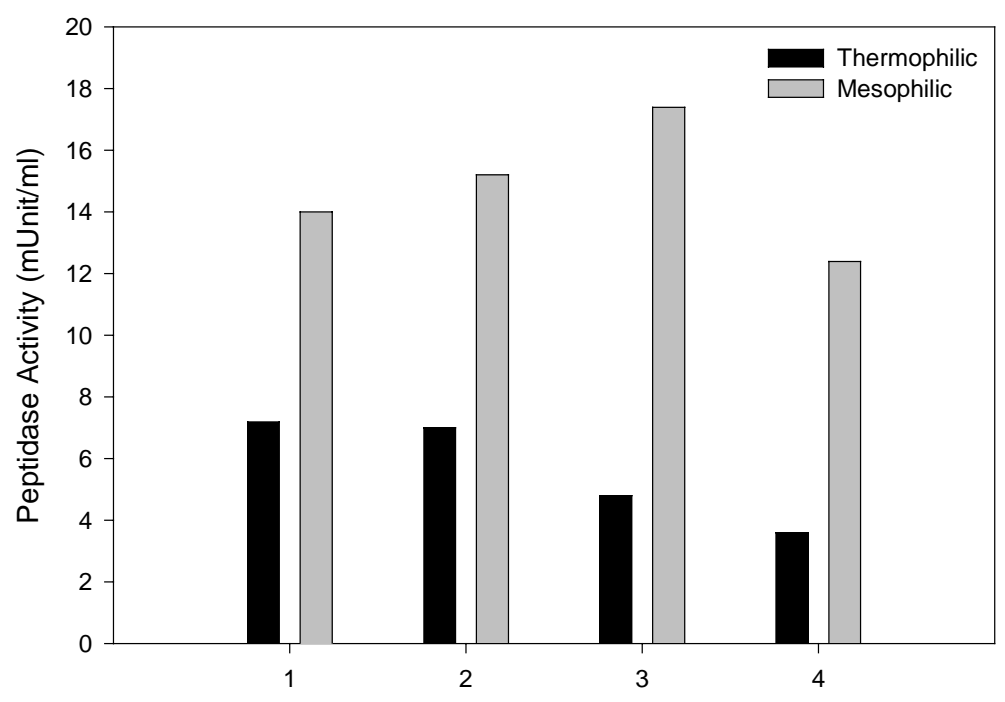


FIGURE 6: Volatile Fatty Acid Concentration Across the Digesters

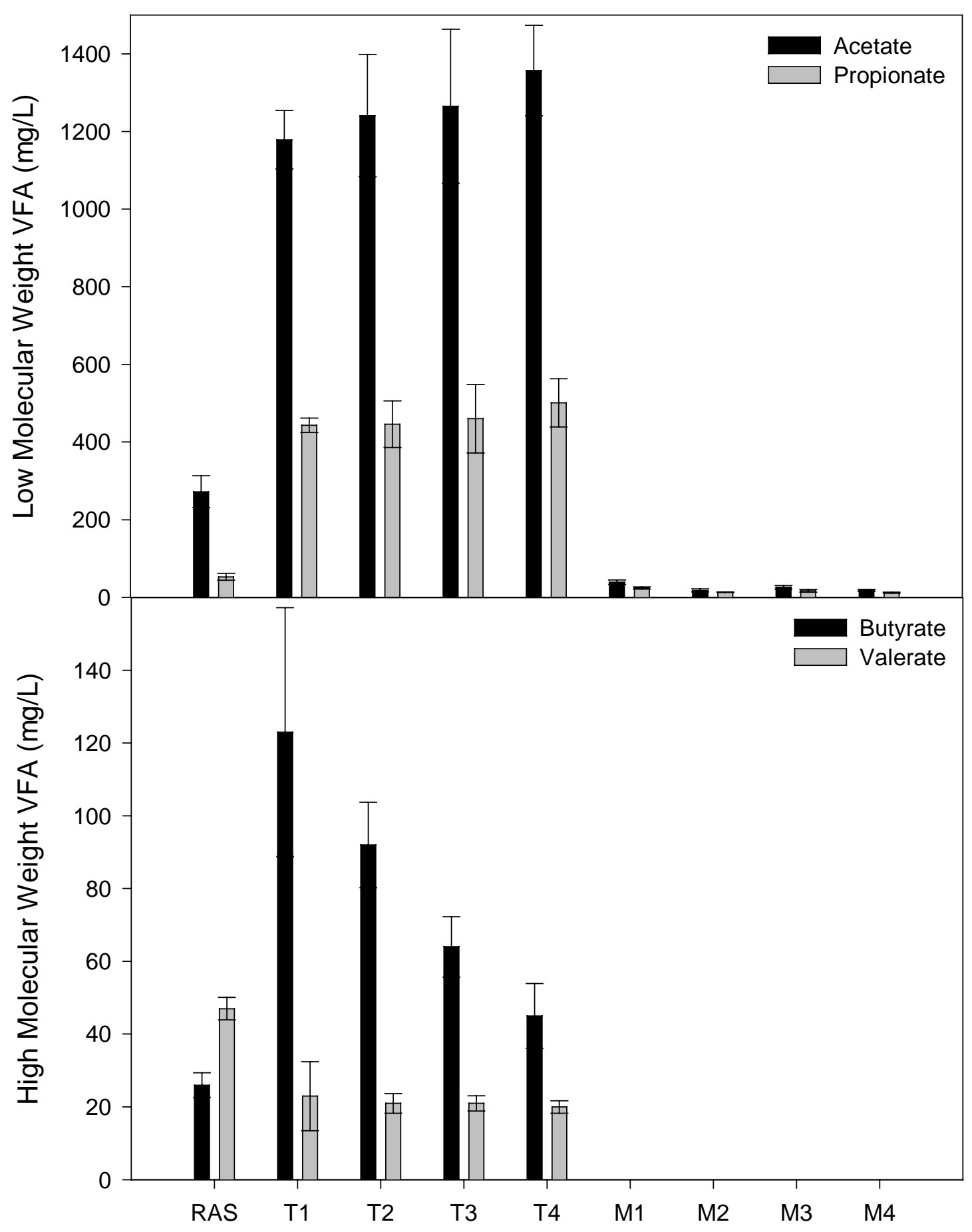


FIGURE 7: Filterable Ammonium Ion $\left(\mathrm{NH}_{4}-\mathrm{N}\right)$ Concentration Across the Digester

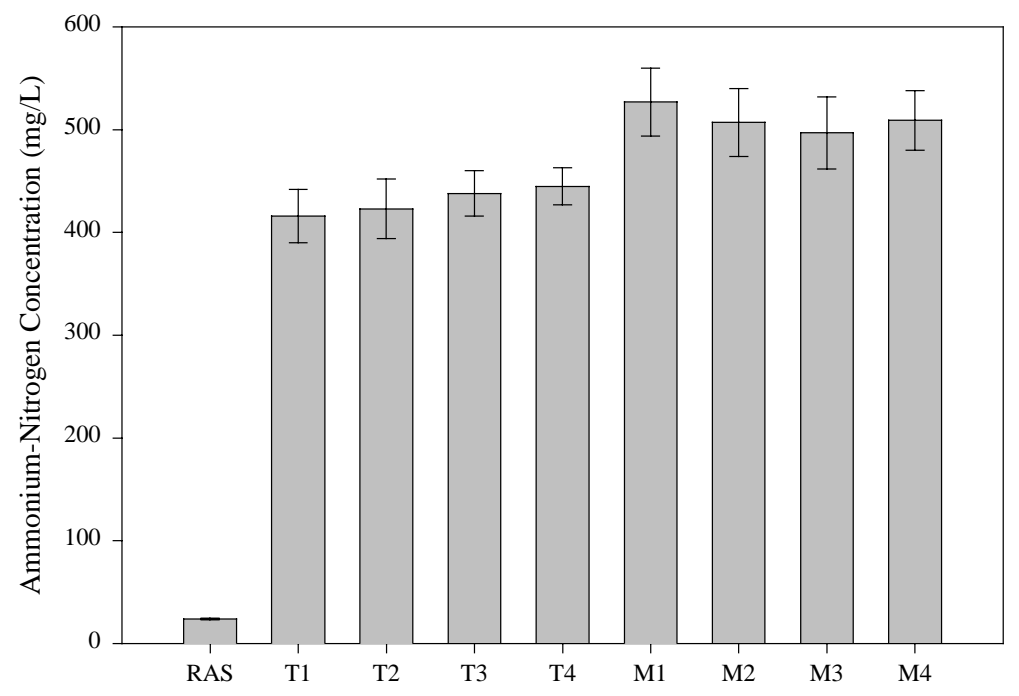


FIGURE 8: Filterable Magnesium and Phosphate $\left(\mathrm{PO}_{4}-\mathrm{P}\right)$ Concentration Across the Digesters

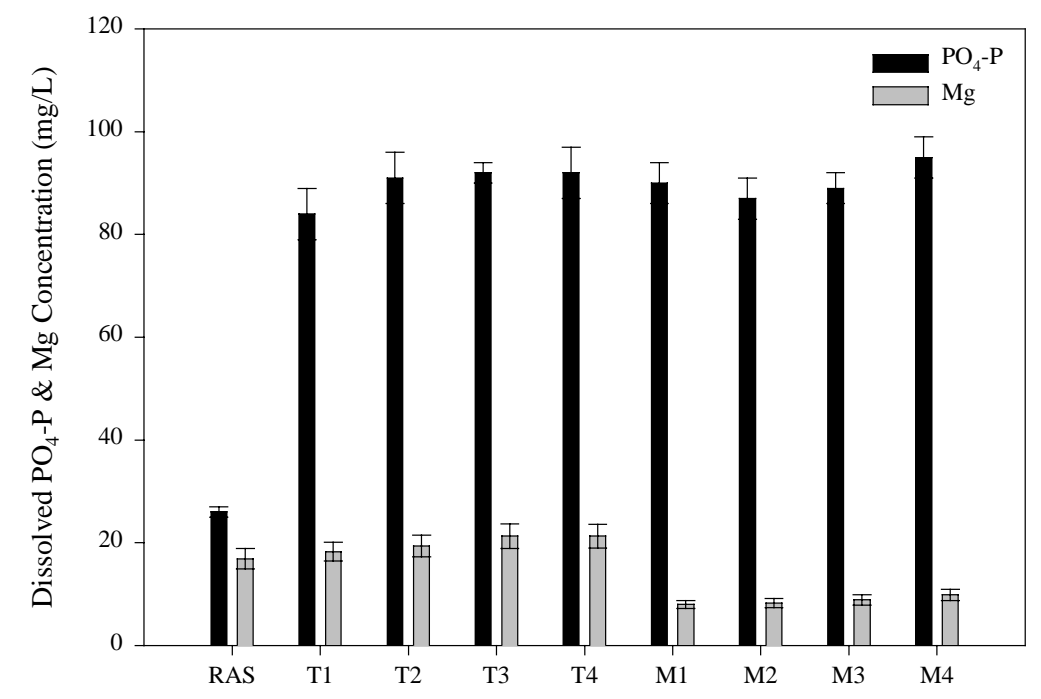




\section{SUMMARY OF EXPERIMENTAL SYSTEM DATA}

TABLE 2: Summary of Experimental System Data (Average Values).

\begin{tabular}{|c|c|c|c|c|c|c|c|c|c|c|c|c|c|}
\hline & UNITS & RAS & T1 & T2 & T3 & T4 & M1 & M2 & M3 & M4 & RAS & \begin{tabular}{|l|} 
THERMO \\
\end{tabular} & MESO \\
\hline $\mathrm{Na}$ & $\mathrm{mg} / \mathrm{L}$ & 86 & 86 & 86 & 85 & 84 & 72 & 71 & 70 & 71 & 86 & 85 & 71 \\
\hline NH4-H & $\mathrm{mg} / \mathrm{L}$ & 24 & 416 & 423 & 438 & 445 & 527 & 507 & 497 & 509 & 24 & 430 & 510 \\
\hline $\mathrm{K}$ & $\mathrm{mg} / \mathrm{L}$ & 34 & 71 & 71 & 70 & 77 & 68 & 68 & 68 & 69 & 34 & 72 & 68 \\
\hline $\mathrm{Mg}$ & $\mathrm{mg} / \mathrm{L}$ & 17 & 18 & 19 & 21 & 21 & 8 & 8 & 9 & 10 & 17 & 20 & 9 \\
\hline $\mathrm{Ca}$ & $\mathrm{mg} / \mathrm{L}$ & 36 & 24 & 25 & 26 & 27 & 25 & 23 & 23 & 25 & 36 & 26 & 24 \\
\hline PO4-P & $\mathrm{mg} / \mathrm{L}$ & 26 & 84 & 91 & 92 & 92 & 90 & 87 & 89 & 95 & 26 & 90 & 90 \\
\hline SO4 & $\mathrm{mg} / \mathrm{L}$ & 93 & 6 & 9 & 14 & 15 & 0 & 0 & 0 & 0 & 93 & 11 & 0 \\
\hline Protein & $\mathrm{mg} / \mathrm{L}$ & 59 & 702 & 731 & 784 & 853 & 181 & 189 & 202 & 193 & 59 & 768 & 191 \\
\hline Polysac & $\mathrm{mg} / \mathrm{L}$ & 20 & 128 & 149 & 167 & 188 & 76 & 72 & 73 & 85 & 20 & 158 & 77 \\
\hline COD & $\mathrm{mg} / \mathrm{L}$ & 375 & 4704 & 5063 & 5263 & 5422 & 2153 & 2512 & 3030 & 2432 & 375 & 5113 & 2532 \\
\hline $\mathrm{Fe}$ (Dissolved) & $\mathrm{mg} / \mathrm{L}$ & 1.80 & 3.40 & 3.50 & 4.10 & 4.40 & 1.42 & 1.62 & 1.88 & 1.90 & 1.80 & 3.85 & 1.71 \\
\hline Acetate & $\mathrm{mg} / \mathrm{L}$ & 272 & 1179 & 1241 & 1265 & 1357 & 39 & 18 & 26 & 18 & 272 & 1260 & 25 \\
\hline Propionate & $\mathrm{mg} / \mathrm{L}$ & 53 & 443 & 446 & 460 & 501 & 24 & 13 & 17 & 12 & 53 & 463 & 17 \\
\hline Butyrate & $\mathrm{mg} / \mathrm{L}$ & 26 & 123 & 92 & 64 & 45 & 0 & 0 & 0 & 0 & 26 & 81 & 0 \\
\hline Valerate & $\mathrm{mg} / \mathrm{L}$ & 47 & 23 & 21 & 21 & 20 & 0 & 0 & 0 & 0 & 47 & 21 & 0 \\
\hline $\mathrm{Fe}$ (Total) & $\mathrm{mg} / \mathrm{kg}$ & 7013 & 6578 & 6800 & 6884 & 7026 & 8519 & 8435 & 8804 & 8525 & 7013 & 6822 & 8571 \\
\hline Total Solids & $\%$ & 1.6759 & 1.3624 & 1.3204 & 1.2699 & 1.1836 & 1.1001 & 1.0731 & 1.1000 & 1.0822 & 1.6759 & 1.2841 & 1.0888 \\
\hline CST & $\sec$ & & 709 & 791 & 842 & 896 & 846 & 936 & 1093 & 1175 & & 810 & 1013 \\
\hline Polymer (CST $=50)$ & $\mathrm{g} / \mathrm{kg}$ & & 75 & 82 & 85 & 90 & 72 & 81 & 85 & 86 & & 83 & 81 \\
\hline $\mathrm{FeCl} 3(\mathrm{CST}=50)$ & $\mathrm{g} / \mathrm{kg}$ & & 186 & 194 & 201 & 208 & 184 & 190 & 203 & 218 & & 198 & 199 \\
\hline Peptidase Activity & $\mathrm{mUnit} / \mathrm{ml}$ & & 7.2 & 7.0 & 4.8 & 3.6 & 14.0 & 15.2 & 17.4 & 12.4 & & 5.7 & 14.8 \\
\hline & & & & & & & & & & & & & \\
\hline & & \multicolumn{3}{|c|}{ Protein } & \multicolumn{3}{|c|}{ Polysaccharide } & \multicolumn{3}{|c|}{$\mathrm{COD}$} & \multicolumn{3}{|c|}{ Colloidal Fraction $(\mathrm{mg} / \mathrm{L})$} \\
\hline & & \multicolumn{3}{|c|}{ AVG (mg/L) } & \multicolumn{3}{|c|}{ AVG (mg/L) } & \multicolumn{3}{|c|}{ AVG (mg/L) } & \multicolumn{3}{|c|}{ (1.5 u to $30 \mathrm{~K} \mathrm{amu})$} \\
\hline & & $1.5 \mathrm{u}$ & $30 \mathrm{~K}$ AMU & $1 \mathrm{~K}$ AMU & $1.5 \mathrm{u}$ & $30 \mathrm{~K}$ AMU & $1 \mathrm{~K}$ AMU & $1.5 \mathrm{u}$ & $30 \mathrm{~K}$ AMU & $1 \mathrm{~K}$ AMU & Protein & Polysac & COD \\
\hline & RAS & 59 & 49 & 41 & 20 & 5 & 0 & 375 & 311 & 271 & 10 & 15 & 63 \\
\hline & T1 & 702 & 497 & 462 & 128 & 39 & 7 & 4704 & 3708 & 3827 & 205 & 89 & 996 \\
\hline & $\mathrm{T} 2$ & 731 & 516 & 490 & 149 & 45 & 9 & 5063 & 3907 & 3907 & 215 & 103 & 1157 \\
\hline & $\mathrm{T} 3$ & 784 & 544 & 510 & 167 & 50 & 11 & 5262 & 3987 & 4146 & 240 & 117 & 1275 \\
\hline & T4 & 853 & 607 & 571 & 188 & 58 & 13 & 5422 & 4186 & 4186 & 246 & 130 & 1236 \\
\hline & M1 & 181 & 75 & 45 & 76 & 15 & 7 & 2153 & 1355 & 319 & 105 & 61 & 798 \\
\hline & M2 & 189 & 73 & 43 & 72 & 14 & 4 & 2512 & 1316 & 439 & 115 & 58 & 1196 \\
\hline & M3 & 202 & 71 & 49 & 73 & 15 & 5 & 3030 & 1475 & 638 & 131 & 57 & 1555 \\
\hline & M4 & 193 & 72 & 51 & 85 & 17 & 5 & 2432 & 1515 & 877 & 121 & 68 & 917 \\
\hline & RAS & 10 & 15 & 63 & 10 & 15 & 63 & 10 & 15 & 63 & 10 & 15 & 63 \\
\hline & \begin{tabular}{|l|} 
Thermo \\
\end{tabular} & 227 & 110 & 1166 & 227 & 110 & 1166 & 227 & 110 & 1166 & 227 & 110 & 1166 \\
\hline & Meso & 118 & 61 & 1117 & 118 & 61 & 1117 & 118 & 61 & 1117 & 118 & 61 & 1117 \\
\hline
\end{tabular}




\section{TPAD PILOT PLANT STUDY}

A sludge characterization study was performed on samples obtained from a pilot plant operated by Infilco Degremont Inc. at the Belmont AWT facility in Indianapolis. The plant was operated in a semi-continuous mode; sludge was fed and withdrawn from the system every 12 hours. The following sludges were analyzed: mixed sludge (untreated), acidogenic sludge $\left(55^{\circ} \mathrm{C}, \mathrm{HRT}=2\right.$ days $)$, and methanogenic sludge $\left(37^{\circ} \mathrm{C}\right.$, HRT $=10$ days). A summary of the sludge characterization study can be seen in Table 3 . It should be noted that the sludge matrices and solids concentrations, as well as the mesophilic SRT's are different than the laboratory-scale TPAD system.

During the pilot study, the RAS contained higher concentrations of filterable biopolymer than that observed during the laboratory-scale study. This can be probably be attributed to a higher total solids concentration in the pilot plant RAS. A substantial increase in filterable biopolymer concentration was observed during thermophilic digestion in both studies. During mesophilic digestion, both the protein and polysaccharide concentrations were approximately the same during both studies. However, it should be noted that the mesophilic digestion SRT for the pilot plant was 10 days while the mesophilic SRT for the lab-scale study was 15 days.

Similar to the laboratory study, the filterable sodium concentration remained relatively constant throughout the entire digestion process. The concentration of filterable potassium remained relatively constant as well. During the laboratory-scale study, the filterable potassium concentration doubled during the thermophilic phase of digestion. As previously discussed, the reason for the variance can probably be attributed to differing upstream treatment processes; the Blacksburg WWTP serves as a biological nutrient removal facility. Filterable ammonium increased substantially during both phases of digestion. During the laboratory-scale study, the filterable ammonium concentration increased significantly during thermophilic digestion; however, the increase was not as substantial during mesophilic digestion. The concentration of filterable magnesium increased slightly during thermophilic digestion, which was similar to the laboratory-scale study. During mesophilic digestion at the pilot plant, the filterable magnesium concentration decreased by about one-third. The filterable magnesium 
concentration decreased by approximately two-thirds during mesophilic digestion in the laboratory-scale reactors. The filterable calcium concentration remained constant during thermophilic digestion and decreased by approximately two-thirds during mesophilic digestion. During the laboratory-scale study, the filterable calcium concentration decreased by approximately one-third during thermophilic digestion and remained relatively constant during mesophilic digestion. The Belmont AWT sludge appears to be calcium selective while the Blacksburg-VPI WWTP sludge appears to be magnesium selective.

The filterable iron concentrations cannot be compared because ferric chloride was added to the feed of the pilot plant to reduce odor. However, it should be noted that the filterable iron concentration decreased significantly (97\%) during mesophilic digestion at the pilot plant.

As noted earlier, the total solids concentration was significantly higher during the pilot plant study; however, the percent change in solids concentration can be compared. Solids destruction during thermophilic digestion was approximately the same during both studies, approximately 25 percent. However, the solids destruction during mesophilic digestion varied significantly. Approximately 20 percent more solids were destroyed during the mesophilic phase of the pilot plant than that observed in the laboratory. This is significant considering the SRT of the pilot plant mesophilic digesters were 5 days less than the lab-scale mesophilic reactors.

A separate dewatering study was performed on the recycled sludge (RS), thermophilic digester sludge (TDS), mesophilic digester sludge (MDS), and the plant mixed sludge (PMS) upstream of the beltpresses. The sludges were treated with PERCOL 7950NR polymer from Allied Colloids Inc. A summary of the findings can be seen in Table 4. The polymer was added at three percent solution and mixed for 30 seconds at $30 \mathrm{rpm}$. The optimum doses were determined based on a CST and SRF analysis. From the previous study, it can be seen that the CST of the unconditioned sludges increased during thermophilic digestion and decreased during mesophilic digestion. The cake solids following dewatering were similar (21-24\%) except for the mesophilic digested sludge (15\%). The total solids concentration is reduced significantly 
during mesophilic digestion. However, unlike the laboratory-scale study, the dewatering properties appear to deteriorate during both phases of digestion.

TABLE 3: Pilot Plant Sludge Characterization Study. The filterable form of each parameter was measured.

\begin{tabular}{|l|c|c|c|}
\hline \multicolumn{1}{|c|}{ Parameter } & Mixed & Acidogenic & Methanogenic \\
\hline Sodium (mg/L) & 139 & 137 & 145 \\
\hline Ammonium-Nitrogen (mg/L) & 100 & 325 & 560 \\
\hline Potassium (mg/L) & 64 & 76 & 70 \\
\hline Magnesium (mg/L) & 73 & 89 & 58 \\
\hline Calcium (mg/L) & 518 & 563 & 210 \\
\hline Polysaccharide (mg/L) & 142 & 357 & 101 \\
\hline Protein (mg/L) & 276 & 705 & 182 \\
\hline Acetate (mg/L) & 1376 & 1616 & 47 \\
\hline Iron $(\mathrm{mg} / \mathrm{L})$ & 790 & 963 & 25 \\
\hline Cake Solids (\%) & 6.44 & 4.73 & 2.78 \\
\hline CST (sec) & 1228 & 1577 & 926 \\
\hline
\end{tabular}

TABLE 4: Pilot Plant Dewatering Study

\begin{tabular}{|l|c|c|c|c|}
\hline & RS & PMS & TDS & MDS \\
\hline Cake Solids (\%) & 4.25 & 4.43 & 4.81 & 2.60 \\
\hline Optimum Dose $(\mathrm{g} / \mathrm{kg})$ & 45 & 45 & 90 & 136 \\
\hline
\end{tabular}




\section{ENGINEERING SIGNIFICANCE}

Until recently, research and design efforts have focused on the liquid side of wastewater treatment operations and treated solids handling and biosolids management as secondary issues. However, solids related facilities can account for nearly 50 percent of the total capital and annual cost for treatment operations. Also, public scrutiny over land application has drastically increased in recent years. Therefore, solids handling and biosolids management has been and will continue to be one of the most difficult and expensive aspects of wastewater treatment.

Although Class A biosolids can be achieved by TPAD systems at reasonable retention times, thermophilically digested sludges often require higher chemical dosages, yield wetter cakes, and have a poorer quality of filtrate or centrate than mesophilically digested sludges. Each of these characteristics can have a drastic impact on the expense and effectiveness of treatment operations.

The results of this study suggest that the deterioration of dewatering properties during thermophilic digestion can be attributed to proteins and polysaccharides in colloidal size fraction. During this study, the mesophilic digestion time was maintained at 15 days for each set-up. It can be speculated that increasing the mesophilic retention time in TPAD systems may improve dewatering properties by enabling longer time for degradation and/or reflocculation of colloidal biopolymer. However, larger reactors would be required to increase the mesophilic detention time, likely offsetting any economic gains realized by improved dewatering properties.

The rate of protein degradation appears to be attributable to enzymatic activity; however, parameters affecting enzymatic activity are unknown. Also, magnesium appears to play a role in the reflocculation of filterable protein. Future research efforts should focus on methods to reduce the release and/or production, as well as increase the degradation and/or reflocculation of colloidal biopolymer.

Although great strides have been made in recent years, the mechanisms of dewatering are still not fully understood. To some extent, the dewatering process is a "black box." Physical, chemical and biological properties of sludges vary based on wastewater sources and upstream unit processes. Therefore, optimizing dewatering operations is often an ongoing process of trial and error. Given the expense associated 
with dewatering, specifically with thermophilic digestion systems, further research is warranted. 


\section{VITA}

Jason Lee Bivins was born on October 6, 1973 in Owensboro, Kentucky. He graduated from Daviess County High School in May of 1992. In December of 1996, he received a B.S. in Civil Engineering from the University of Kentucky. In August of 1997, he started work on his Master's degree in Environmental Engineering at Virginia Polytechnic Institute and State University. He is currently employed by USFilter Kruger Products in Cary, North Carolina, as a process engineer. 